\title{
Periphytic diatoms from an oligotrophic lentic system, Piraquara I reservoir, Paraná state, Brazil
}

\author{
Angela Maria da Silva-Lehmkuhl ${ }^{1,2 *} \mathbb{B}$, Priscila Izabel Tremarin ${ }^{3}$, Ilka Schincariol Vercellino $^{4} \&$ \\ Thelma A. Veiga Ludwig ${ }^{5}$ \\ ${ }^{1}$ Universidade Federal do Amazonas, Estrada Parintins Macurany, 1805, 69152-240, Parintins, AM, Brasil \\ ${ }^{2}$ Universidade Estadual Paulista Julio de Mesquita Filho, 13506-900, Rio Claro, SP, Brasil \\ ${ }^{3}$ Acqua Diagnósticos Ambientais Ltda., Curitiba, PR, Brasil \\ ${ }^{4}$ Centro Universitario São Camilo, São Paulo, SP, Brasil \\ ${ }^{5}$ Universidade Federal do Paraná, Av. Cel. Francisco H. dos Santos, Jardim das Américas, 81531980, \\ Curitiba, PR, Brasil \\ *Corresponding author: Angela Maria da Silva-Lehmkuhl,e-mail: angela_ecologia@yahoo.com.br
}

\begin{abstract}
SILVA-LEHMKUHL, A.M., TREMARIN, P.I., VERCELLINO, I.S., LUDWIG, T.A.V. Periphytic diatoms from an oligotrophic lentic system, Piraquara I reservoir, Paraná state, Brazil. Biota Neotropica. 19(2): e20180568. http://dx.doi.org/10.1590/1676-0611-BN-2018-0568
\end{abstract}

\begin{abstract}
Knowledge of biodiversity in oligotrophic aquatic ecosystems is fundamental to plan conservation strategies for protected areas. This study assessed the diatom diversity from an urban reservoir with oligotrophic conditions. The Piraquara I reservoir is located in an Environmental Protection Area and is responsible for the public supply of Curitiba city and the metropolitan region. Samples were collected seasonally between October 2007 and August 2008. Periphytic samples were obtained by removing the biofilm attached to Polygonum hydropiperoides stems and to glass slides. The taxonomic study resulted in the identification of 87 diatom taxa. The most representative genera regarding the species richness were Pinnularia (15 species) and Eunotia (14 species). Five species were registered for the first time in Brazil and seven in the State of Paraná. Taxonomic and ecological comments of the species registered are provided.
\end{abstract}

Keywords: artificial substrate, diatom ecology, macrophytes, reservoirs.

\section{Diatomáceas perifíticas de um sistema lêntico oligotrófico, reservatório do Piraquara I, estado do Paraná, Brasil}

Resumo: O conhecimento da biodiversidade em ecossistemas aquáticos oligotróficos é fundamental para planejar estratégias de conservação de áreas protegidas. Este estudo teve como objetivo conhecer a diversidade de diatomáceas em um reservatório urbano com condições oligotróficas. O reservatório do Piraquara I está inserido em uma Área de Proteção Ambiental em região de manancial e é responsável pelo abastecimento público de Curitiba e região metropolitana. Foram realizadas coletas estacionais entre os meses de outubro de 2007 e agosto de 2008. As amostras perifíticas foram obtidas pela remoção do biofilme aderido a caules de Polygonum hydropiperoides e de lâminas de vidro. O estudo taxonômico resultou na identificação de 87 táxons. Os gêneros mais representativos, considerando a riqueza de espécies, foram Pinnularia (15 espécies) e Eunotia (14 espécies). Cinco espécies de diatomáceas foram registradas pela primeira vez no Brasil e sete no estado do Paraná. Comentários taxonômicos e ecológicos também são apresentados para as espécies encontradas.

Palavras-chave: substrato artificial, ecologia de diatomáceas, macrófitas, reservatório. 


\section{Introduction}

Diatoms are considered one of the most representative groups of microalgae due to the number of described species. Approximately 12,000 species of diatoms have been described hitherto (Guiry 2012) although the estimated number of species is thought to be at least 30,000 (Mann e Vanormeligen 2013). Diatoms are excellent bioindicators of water quality, being sensible to environmental pollution and a number of anthropogenic pressures, such as the increase in nutrient concentrations, acidification, land use, and the presence of toxic chemicals dissolved in water (Leskinen \& Hällfors 1990, Lowe \& Pan 1996, Lobo et al. 2002, Rimet et al. 2015).

Diatoms release mucilage through raphe, rimoportulae and apical pore fields, facilitating the frustule adhesion to different types of substrates. This strategy contributes to diatoms representativeness in the periphytic community (Round et al. 1990, Lowe 1996). The species composition of periphytic assemblages can be influenced by the substrate micro-topography (Murdock and Dodds 2007, Souza \& Ferragut 2012). Inventories using substrates with different surface types usually hold a great algal diversity (Ács et al. 2000). Therefore, diatom inventories should be carried out in a great number of different environments and using diverse substrates to maximize the recovery of new species, extend the distribution of known species and better define their ecological preferences, which increase the reliability of environmental diagnostics.

Man-made lentic environments with oligotrophic conditions are rare in urban areas and are examples of environmental health. Unfortunately, human activities in the surrounding watershed have been accelerating the processes of eutrophication, affecting the water quality and the biodiversity, leading to the loss of important ecological functions (Tundisi 2003, Torrisi et al. 2010). Due to the undesirable impact of these activities on the water physical and chemical conditions, efforts have been generally focused on studying eutrophic environments rather than on preserving oligotrophic water bodies. For this reason, there is usually a gap in the knowledge of the algal diversity of protected areas, which creates exceptional opportunities to study the remaining oligotrophic environments (Kociolek \& Stoermer 2009).

Recent studies in oligotrophic Brazilian reservoirs contributed to the description of new diatom species in the genera Kurtkrammeria and Encyonema (Marquardt et al. 2016, Marquardt et al. 2017) and extended the geographic distribution of the already known species (Canani et al. 2011). Paleolimnological studies with diatoms are important in providing a further understanding of biodiversity, detecting the response of the assemblages over time. Generally, a decrease in the diatom diversity during the eutrophication process can be observed when comparing environments that were oligotrophic but are currently eutrophised (Faustino et al. 2016, Wengrat et al. 2017).

Previous diatom inventories were carried out in urban reservoirs of the Iguaçu river basin along a trophic gradient ranging from mesotrophic (Passaúna, Bertolli et al. 2010 and Piraquara II, Marra et al. 2016), eutrophic (Iraí, Silva et al. 2010) to hypereutrophic (Itaqui, Faria et al. 2010). The Piraquara I reservoir, which was surveyed in the present study, is connected to Piraquara II reservoir. The macrophyte Polygonum hydropiperoides Michaux and glass slides were used as substrates to assess the periphytic diatoms in these reservoirs.

The present study aimed at assessing the composition of periphytic diatom assemblages from the oligotrophic reservoir Piraquara I. We provided measures, illustrations, taxonomical comments and ecological data based on scientific literature, in order to contribute to the knowledge of Brazilian diatoms from oligotrophic environments.

\section{Material and Methods}

The Piraquara I Reservoir (25³0'24.16” S, 49¹'29.4” W) is a man-made public water supply of the Iguaçu River basin located in an Environmental Protection Area which is in a transition zone between the dense and mixed ombrophilous forest. The Cayuguava river was dammed to construct the reservoir in 1979 (Figure 1) (Guimarães 2008). The reservoir has a $3.3 \mathrm{~km}^{2}$ of flooded area, 7 meters in depth, a flow rate of $600 \mathrm{l} / \mathrm{s}$, and a water residence time of 438 days (Júnior et al. 2005).

The physical and chemical data were provided by the Paraná Environmental Institute (IAP) (unpublished data) and by the water company of Paraná State (SANEPAR) (unpublished data). The Trophic State Index (TSI) was calculated according to Lamparelli (2004) (Zorzal-Almeida et al. 2017).

Samplings were carried out seasonally (i.e. in spring, summer, autumn, and winter) from October 2007 to August 2008, at two sampling stations. Periphytic samples were obtained from natural and artificial substrates. As natural substrates, we used stems of the macrophyte Polygonum hydropiperoides Michaux that were collected near the reservoir margin. The periphyton was obtained by scraping the stems with a razor blade wrapped in foil. Glass slides $(7.5 \mathrm{~cm} \times 2.5 \mathrm{~cm})$ were used as artificial and inert substrates fixed to woody frames that were left submerged in the water column for 30 days. The artificial substrates were placed at about 80 meters far from the margin of the reservoir to prevent being eventually trapped in the macrophytes by the wind action.

Substrate fragments were fixed in Transeau's solution (6:3:1) (Bicudo \& Menezes 2017). The samples were treated by oxidation according to the method of Simonsen (1974) modified by MoreiraFilho \& Valente-Moreira (1981). The material was air-dried onto glass slides and mounted in Naphrax ${ }^{\circledR}$ resin. Observations, measurements, and diatom photomicrographs were performed at $1000 \times$ magnification in an Olympus BX40 microscope equipped with a DP71 Olympus camera. Diatom identification was performed up to the lowest level of taxonomic hierarchy based on recent and classic literature (e.g. Lange-Bertalot 1993, 1999, 2001, Lange-Bertalot \& Metzeltin 1996, Metzeltin \& Lange-Bertalot 1998, 2002, 2005, 2007, Bahls 2015). For each taxon, we included information on morphometry, remarks on the autoecology (when available in literature) as well as on the occurrence in the samples (see also table 2). Taxonomic comments were provided only for poorly known species in Brazil. We considered that a species is recorded for the first time in Brazil and in the state of Paraná if it was not previously recorded in a published article. The studied materials were deposited at the herbarium of the State University of Paraná (UPCB) under the numbers 63371 to 63374 (glass slides) and 63375 to 63378 (macrophyte $P$. hydropiperoides).

\section{Results and Discussion}

The Piraquara I reservoir was classified as oligotrophic by the TSI index, characterized by low concentrations of phosphorus and nitrogen, high transparency of the water column (up to 3.2 meters), and a slightly acid to nearly neutral $\mathrm{pH}$. Summer showed the highest 


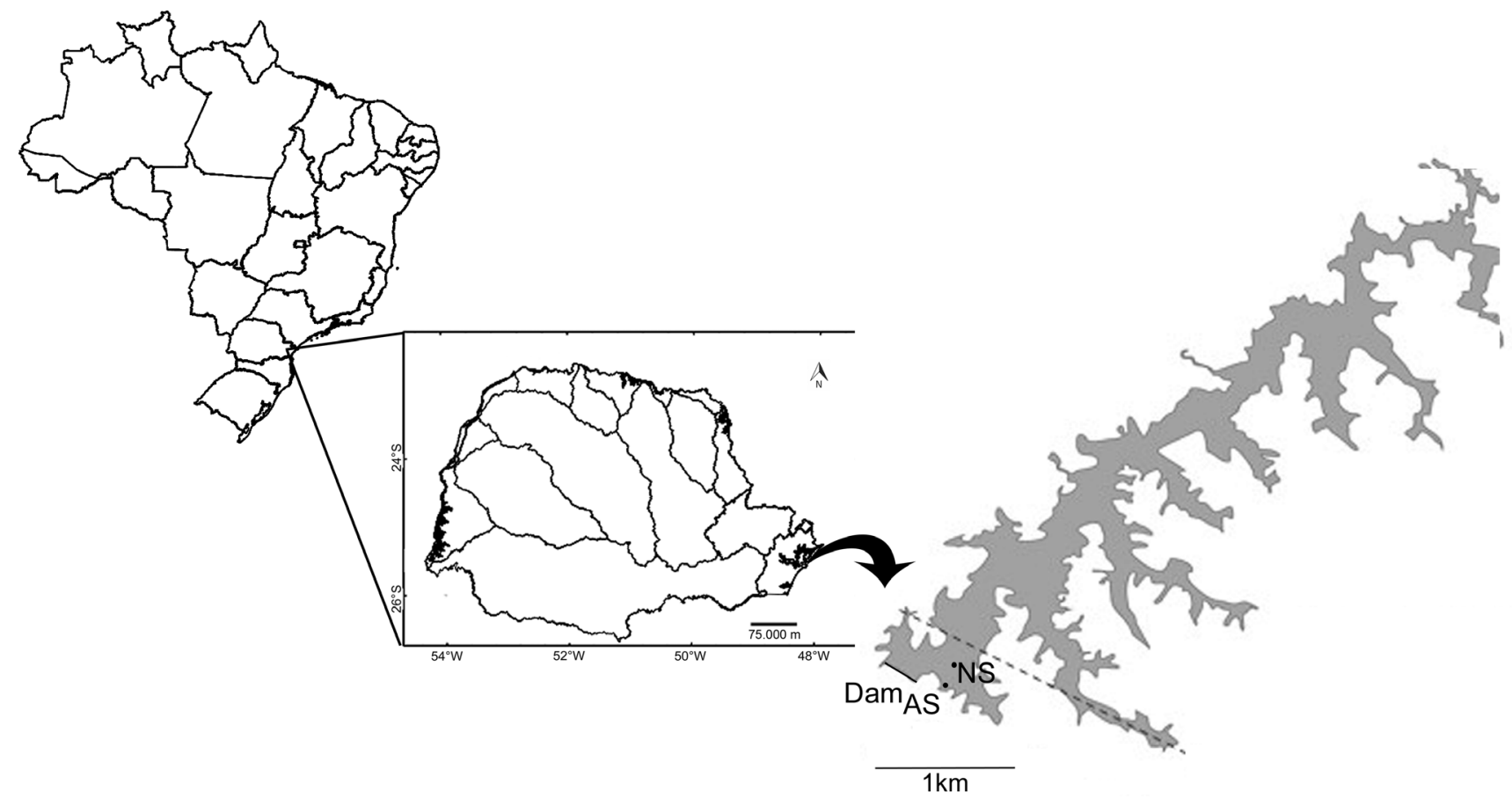

Figure 1. Sampling site in Piraquara I reservoir, Paraná state, Brazil. Artificial Substrate (AS) and Natural Substrate (NS). (shapefile map from SUDERHSA 2007).

values of temperature and accumulated rainfall occurred in the summer sample $\left(27^{\circ} \mathrm{C}\right.$ and $326.9 \mathrm{~mm}$, respectively). The physical and chemical water parameters are shown in Table 1.

We identified 88 infrageneric taxa that belong to 35 genera. Pinnularia Ehrenberg (15 spp.) and Eunotia Ehrenberg (14 spp.) were the most representative diatoms in both substrates. The macrophyte P. hydropiperoides showed the highest richness (77) and the highest number of exclusive species (35) that represented $45.4 \%$ of the total substrate richness, whereas the artificial substrate presented 52 species and 10 exclusive taxa, which corresponded to $19.2 \%$ of the total substrate richness.
The species first recorded in Brazil were Achnanthidium neomicrocephalum Lange-Bertalot \& Staab, Craticula riparia var. mollenhaurei Lange-Bertalot, Frustulia australocrassinervia Casa, Mataloni \& Van de Vijver, Gomphonema spiculoides Gandhi and Stauroneis neohyalina Lange-Bertalot \& Krammer. Seven diatoms are recorded for the first time in Paraná State: Craticula acidoclinata LangeBertalot \& Metzeltin, Fragilaria billingsii Wengrat, Wetzel \& Morales, Eunotia longicamelus Costa, Bicudo \& Wetzel, Eunotia pseudoimplicata Lange-Bertalot, Costa \& Wetzel, Humidophila biscutella (Moser, Lange-Bertalot \& Mezeltin) Lowe, Kociolek, Johansen, Van de Vijver,

Table 1. Physical and chemical characteristics of the Piraquara I reservoir registered seasonally between October 2007 and August 2008.

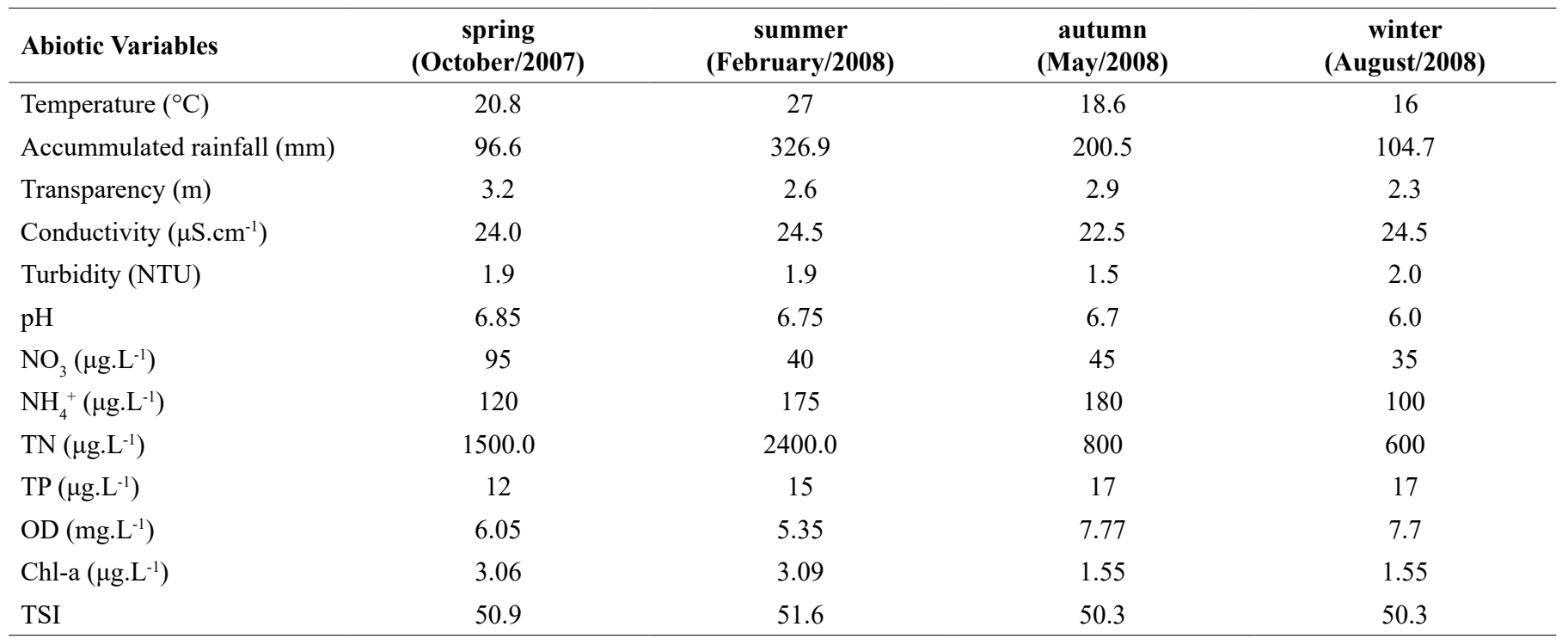


Lange-Bertalot \& Kopalová, Nitzschia semirobusta Lange-Bertalot and Pinnularia viridiformis var. minor Krammer.

Pinnularia and Eunotia (15 and 14 species, respectively) presented a higher species richness in Piraquara I reservoir. The presence of these genera was favored by the slight acidity, low conductivity and water oligotrophy conditions of the studied reservoir (Round et al. 1990, Metzeltin \& Lange-Bertalot 1998, Spaulding \& Edlund 2009, Costa et al. 2017). Eunotia was also the most representative genus in a eutrophic reservoir (Silva et al. 2010) located near to the Piraquara I. However, only three Eunotia species (E. naegelii, E. minor and E. subarcuatoides), which have a wide tolerance to trophic gradients (Van Dam et al. 1994, Silva et al. 2010, Costa et al. 2017) and they are able to occur under oligotrophic and eutrophic conditions, were common to both reservoirs.

The genera Navicula, Gomphonema, and Nitzschia, which are commonly registered in nutrient-rich environments (Goldsborough \& Robinson 1996), showed a high species number in both substrates at the mesotrophic and hypereutrophic reservoirs located nearby to Piraquara I (Bertolii et al. 2010, Faria et al. 2010, Marra et al. 2016).

The richest assemblage was obtained from Polygonum hydropiperoides (natural substrate), 77 species, and can be explained by the glabrous or pubescent petiole of this macrophyte (Melo 2008), which offers a greater architectural complexity than the smooth and uniform surface of glass slides. The roughness difference between substrates usually does not contribute to an increase in algal biomass, but it is an important factor in selecting the species composition of the periphyton (Burkholder 1996, Souza \& Ferragut 2012).

The diatom species richness found in the oligotrophic Piraquara I reservoir was lower than in the mesotrophic reservoirs Piraquara II and Passaúna (135 and 106 taxa, respectively), the eutrophic reservoir Iraí (96 taxa) and the hypereutrophic reservoir Itaqui (124 taxa) (Bertolli et al. 2010, Silva et al. 2010, Faria 2010, Marra et al. 2016). The Piraquara II is a mesotrophic reservoir located downstream from Piraquara I. Both reservoirs shared the presence of 31 diatom species, of which 11 were recorded from oligotrophic to mesotrophic environments and 20 species had a wide trophic tolerance. The diatom assemblage had more species that are tolerant in Piraquara II than in Piraquara I. Although eutrophication might lead to a loss in diatom diversity (Wengrat et al. 2017), the species richness in shallow lakes might be also influenced by the presence, abundance and diversity of macrophytes (Sayer et al. 1999, Bicudo et al. 2007). Piraquara II and Itaqui had more diatom richness than the other reservoirs, which can be related to the fact that in the former reservoir were sampled three different species of macrophytes (Marra et al. 2016), and that the latter reservoir was almost totally covered by the floating macrophyte Pistia stratiotes L. (Faria et al. 2010, Faria et al. 2013).

Summer showed the highest accumulated rainfall $(326.9 \mathrm{~mm})$ during the sampling period and the lowest species number in both substrates. High rainfall lead to the detachment of the periphyton from the substrates (Casartelli et al. 2016), which certainly contributed to the less number of species registered in Piraquara I. We registered nine diatom species (Spicaticribra kingstonii, Eunotia intermedia, Eunotia parasiolii, Eunotia pseudoimplicata, Encyonopsis subminuta, Cymbopleura naviculiformis, Planothidium incuriatum, Capartogramma crucicula and Nitzschia nana) that occurred in spring on both substrates, but were not recorded in summer. These species release mucilage and remain attached to the substrates and are therefore commonly observed from the periphytic samples (Round et al. 1990, Santos et al. 2011, MontoyaMoreno et al. 2011). In summer, we registered temporary losses of species that were retrieved again during the sampling period. As shown in Table 2, the planktonic and benthic diatoms registered were Aulacoseira ambigua, Cyclotella meneghiniana, Fragilaria recapitellata, Fragilaria sp., Ulnaria delicatissima, Eunotia intricans, Eunotia paratridentula, Encyonopsis schubartii, Achnanthidium minutissimum, Achnanthidium sp., Sellaphora tridentula, Pinnularia brauniana, Pinnularia divergens var. media, Pinullaria obscura, Pinnularia pseudosudetica, Navicula leptostriata, Nitzschia acidoclinata and Nitzschia semirobusta.

\section{Diatoms taxonomy and ecology}

\section{Family STEPHANODISCACEAE}

Spicaticribra kingstonii Johansen, Kociolek \& Lowe

Figure: 2A

Valve diameter: $14.8-15.2 \mu \mathrm{m}$; areolae: 13 in $10 \mu \mathrm{m}$; fultoportulae: 3-5 per valve; rimoportulae: $1-3$ per valve.

In Brazil, this species was described by Ludwig et al. (2008) as Thalassiosira rudis Tremarin, Ludwig, Becker \& Torgan and later synonimized with $S$. kingstonii by Rivera \& Cruces (2013).

Ecology: previously registered in Brazilian tropical and subtropical reservoirs with oligotrophic to eutrophic conditions (Bartozek et al. 2018, Silva et al. 2010, Bertolli et al. 2010), and neutral pH with moderate conductivity (Ludwig et al. 2008). In our samples, it occurred in circumneutral $\mathrm{pH}(6.85)$, low conductivity $(24 \mu \mathrm{S} \mathrm{cm-1})$ and oligotrophic conditions, only in spring (temperature $<21^{\circ} \mathrm{C}$ ),

Occurrence in samples: artificial substrates (UPCB 63371).

\section{Cyclotella meneghiniana Kützing}

\section{Figure: 2B}

Valve diameter: $10-12 \mu \mathrm{m}$; striae: 16 in $10 \mu \mathrm{m}$; rimoportulae: $1-2$ per valve.

Ecology: it is recorded in oligotrophic to eutrophic environments, with a higher abundance in eutrophic waters (Bartozek et al. 2018, Silva et al. 2010) and in acidic waters (van Dam et al. 1994). In our samples, it occurred in slightly acid to circumneutral $\mathrm{pH}$ (6-6.85), low conductivity (24-24.5 $\mu \mathrm{S} \mathrm{cm}$ ) and oligotrophic conditions, in spring and winter (temperature $<21^{\circ} \mathrm{C}$ ).

Occurrence in samples: artificial (UPCB 63374) and natural (UPCB 63375; UPCB 63378) substrates.

\section{Discostella stelligera (Cleve \& Grunow) Houk \& Klee Figure: 2C}

Valve diameter: $12-21 \mu \mathrm{m}$; striae: 9.6-18.3 in $10 \mu \mathrm{m}$.

Ecology: common in oligo-mesotrophic environments (Yang \& Dickman 1993, Potapova \& Charles 2007), and in alkaline waters with high conductivity (Bartozek et al. 2018). It was common in our samples, in slightly acid to circumneutral $\mathrm{pH}$ (6-6.85), low conductivity (24-24.5 $\left.\mu \mathrm{S} \mathrm{cm}{ }^{-1}\right)$ and oligotrophic conditions.

Occurrence in samples: artificial (UPCB 63371; UPCB 63372; UPCB 63373; UPCB 63374) and natural (UPCB 63375; UPCB 63376; UPCB 63377; UPCB 63378) substrates. 
Periphytic diatoms from an oligotrophic reservoir

Table 2. Diatom species and seasonal occurrence on artificial and natural substrates in Piraquara I reservoir.

\begin{tabular}{|c|c|c|c|c|c|c|c|c|}
\hline \multirow[b]{2}{*}{ Species } & \multicolumn{4}{|c|}{ Artificial substrates } & \multicolumn{4}{|c|}{ natural substrates } \\
\hline & $\begin{array}{c}\text { spring } \\
\text { (October/2007) }\end{array}$ & $\begin{array}{c}\text { summer } \\
\text { (February/2008) }\end{array}$ & $\begin{array}{c}\text { autumn } \\
\text { (May/2008) }\end{array}$ & $\begin{array}{c}\text { winter } \\
\text { (August/2008) }\end{array}$ & $\begin{array}{c}\text { spring } \\
\text { (October/2007) }\end{array}$ & $\begin{array}{c}\text { summer } \\
\text { (February/2008) }\end{array}$ & $\begin{array}{c}\text { autumn } \\
\text { (May/2008) }\end{array}$ & $\begin{array}{c}\text { winter } \\
\text { (August/2008) }\end{array}$ \\
\hline Spicaticribra kingstonii & $\mathrm{X}$ & - & - & - & - & - & - & - \\
\hline Discostella stelligera & $\mathrm{X}$ & $\mathrm{X}$ & $\mathrm{X}$ & $\mathrm{X}$ & $\mathrm{X}$ & $\mathrm{X}$ & $\mathrm{X}$ & $\mathrm{X}$ \\
\hline Aulacoseira ambigua & $\mathrm{X}$ & - & $\mathrm{X}$ & $\mathrm{X}$ & $\mathrm{X}$ & $\mathrm{X}$ & $\mathrm{X}$ & $\mathrm{X}$ \\
\hline Fragilaria billingsii & $\mathrm{X}$ & $\mathrm{X}$ & $\mathrm{X}$ & $\mathrm{X}$ & $\mathrm{X}$ & $\mathrm{X}$ & $\mathrm{X}$ & $\mathrm{X}$ \\
\hline F. capucina & - & $\mathrm{X}$ & $\mathrm{X}$ & $\mathrm{X}$ & - & $\mathrm{X}$ & $\mathrm{X}$ & $\mathrm{X}$ \\
\hline F. recapitellata & $\mathrm{X}$ & $\mathrm{X}$ & $\mathrm{X}$ & $\mathrm{X}$ & $\mathrm{X}$ & - & - & $\mathrm{X}$ \\
\hline F. tenera & $\mathrm{X}$ & $\mathrm{X}$ & $\mathrm{X}$ & $\mathrm{X}$ & - & $\mathrm{X}$ & $\mathrm{X}$ & - \\
\hline Fragilaria sp. & $\mathrm{X}$ & - & $\mathrm{x}$ & $\mathrm{X}$ & - & - & - & $\mathrm{X}$ \\
\hline U. ulna & - & - & - & - & - & $\mathrm{X}$ & - & - \\
\hline Eunotia desmogonioides & $\mathrm{X}$ & $\mathrm{X}$ & $\mathrm{X}$ & - & $\mathrm{X}$ & $\mathrm{X}$ & $\mathrm{X}$ & $\mathrm{X}$ \\
\hline E. intermedia & $\mathrm{X}$ & - & - & - & - & - & - & - \\
\hline Eunotia intricans & - & - & - & - & $\mathrm{X}$ & - & $\mathrm{X}$ & - \\
\hline E. longicamelus & - & - & - & - & - & - & - & $\mathrm{X}$ \\
\hline E. minor & - & - & - & - & - & - & - & $\mathrm{X}$ \\
\hline E. naegelii & - & - & - & - & - & - & - & $\mathrm{X}$ \\
\hline E. parasiolii & - & - & - & - & $\mathrm{X}$ & - & - & - \\
\hline E. paratridentula & $\mathrm{X}$ & - & $\mathrm{X}$ & - & $\mathrm{X}$ & $\mathrm{X}$ & - & $\mathrm{X}$ \\
\hline E. pseudoimplicata & $\mathrm{X}$ & - & - & - & $\mathrm{X}$ & - & - & - \\
\hline Encyonema neogracile & $\mathrm{X}$ & $\mathrm{X}$ & $\mathrm{X}$ & $\mathrm{X}$ & $\mathrm{X}$ & $\mathrm{X}$ & $\mathrm{X}$ & $\mathrm{X}$ \\
\hline E. silesiacum & $\mathrm{X}$ & - & - & - & $\mathrm{X}$ & $\mathrm{X}$ & - & $\mathrm{X}$ \\
\hline Encyonopsis cf. reichardtii & - & $\mathrm{X}$ & $\mathrm{x}$ & - & - & $\mathrm{X}$ & $\mathrm{X}$ & $\mathrm{X}$ \\
\hline E. schubartii & $\mathrm{X}$ & $\mathrm{X}$ & $\mathrm{x}$ & - & $\mathrm{X}$ & - & $\mathrm{X}$ & - \\
\hline E. subminuta & $\mathrm{X}$ & - & - & - & - & - & - & - \\
\hline Gomphonema gracile & $\mathrm{X}$ & $\mathrm{X}$ & $\mathrm{x}$ & $\mathrm{x}$ & $\mathrm{X}$ & $\mathrm{X}$ & $\mathrm{x}$ & $\mathrm{x}$ \\
\hline G. lagenula & - & - & - & - & - & - & $\mathrm{X}$ & $\mathrm{X}$ \\
\hline G. pantropicum & - & - & - & $\mathrm{X}$ & - & - & - & - \\
\hline G. spiculoides & $\mathrm{X}$ & $\mathrm{X}$ & $\mathrm{X}$ & $\mathrm{X}$ & $\mathrm{X}$ & $\mathrm{X}$ & $\mathrm{X}$ & $\mathrm{X}$ \\
\hline Cymbopleura naviculiformis & - & - & - & - & $\mathrm{X}$ & - & - & - \\
\hline A. minutissium & $\mathrm{X}$ & - & - & $\mathrm{X}$ & $\mathrm{X}$ & - & $\mathrm{X}$ & $\mathrm{X}$ \\
\hline A. neomicrocephalum & - & - & - & $\mathrm{X}$ & - & - & - & - \\
\hline Achnanthidium sp. & $\mathrm{X}$ & - & $\mathrm{X}$ & - & $\mathrm{X}$ & $\mathrm{X}$ & $\mathrm{X}$ & $\mathrm{X}$ \\
\hline Planothidium incuriatum & - & - & - & - & $\mathrm{X}$ & - & - & - \\
\hline Humidophila biscutella & - & - & $\mathrm{x}$ & $\mathrm{x}$ & - & - & - & $\mathrm{X}$ \\
\hline Luticola simplex & - & - & - & - & - & - & - & $\mathrm{X}$ \\
\hline Luticola permuticoides & - & - & - & - & - & $\mathrm{X}$ & - & - \\
\hline
\end{tabular}


Silva-Lehmkuhl, A.M. et al.

Continuation Table 2.

\begin{tabular}{|c|c|c|c|c|c|c|c|c|}
\hline \multirow[b]{2}{*}{ Species } & \multicolumn{4}{|c|}{ Artificial substrates } & \multicolumn{4}{|c|}{ natural substrates } \\
\hline & $\begin{array}{c}\text { spring } \\
\text { (October/2007) }\end{array}$ & $\begin{array}{c}\text { summer } \\
\text { (February/2008) }\end{array}$ & $\begin{array}{c}\text { autumn } \\
\text { (May/2008) }\end{array}$ & $\begin{array}{c}\text { winter } \\
\text { (August/2008) }\end{array}$ & $\begin{array}{c}\text { spring } \\
\text { (October/2007) }\end{array}$ & $\begin{array}{c}\text { summer } \\
\text { (February/2008) }\end{array}$ & $\begin{array}{c}\text { autumn } \\
\text { (May/2008) }\end{array}$ & $\begin{array}{c}\text { winter } \\
\text { (August/2008) }\end{array}$ \\
\hline Frustulia australocrassinervia & $\mathrm{X}$ & $\mathrm{X}$ & $\mathrm{X}$ & $\mathrm{X}$ & $\mathrm{X}$ & $\mathrm{X}$ & $\mathrm{X}$ & $\mathrm{X}$ \\
\hline F. undosa & - & - & $\mathrm{X}$ & $\mathrm{X}$ & - & $\mathrm{X}$ & $\mathrm{X}$ & - \\
\hline Brachysira neoexilis & $\mathrm{X}$ & $\mathrm{X}$ & $\mathrm{x}$ & $\mathrm{X}$ & $\mathrm{X}$ & $\mathrm{X}$ & $\mathrm{X}$ & $\mathrm{X}$ \\
\hline Neidium affine & - & - & - & - & - & - & $\mathrm{x}$ & - \\
\hline S. tridentula & - & - & - & - & $\mathrm{X}$ & - & $\mathrm{X}$ & - \\
\hline Pinnularia borealis & - & - & - & $\mathrm{X}$ & $\mathrm{X}$ & - & - & - \\
\hline P. brauniana & $\mathrm{X}$ & - & $\mathrm{X}$ & $\mathrm{x}$ & $\mathrm{X}$ & - & $\mathrm{X}$ & $\mathrm{X}$ \\
\hline P. divergens var. divergens & - & - & - & - & - & - & $\mathrm{X}$ & - \\
\hline P. divergens var. media & - & - & - & - & $\mathrm{X}$ & - & $\mathrm{X}$ & $\mathrm{X}$ \\
\hline P. rumrichae & - & - & $\mathrm{X}$ & - & $\mathrm{X}$ & $\mathrm{X}$ & - & $\mathrm{X}$ \\
\hline P. schoenfelderi & - & - & - & - & - & - & $\mathrm{X}$ & - \\
\hline P. subcapitata var. elongata & - & - & - & $\mathrm{x}$ & - & - & - & - \\
\hline P. subcapitata var. subrostrata & - & - & $\mathrm{X}$ & - & $\mathrm{X}$ & $\mathrm{X}$ & $\mathrm{X}$ & - \\
\hline P. subgibba var. undulata & - & - & $\mathrm{x}$ & - & $\mathrm{X}$ & $\mathrm{X}$ & $\mathrm{X}$ & - \\
\hline P. submicrostauron & - & - & $\mathrm{x}$ & - & - & $\mathrm{X}$ & $\mathrm{X}$ & - \\
\hline P. viridiformis & - & - & - & - & $\mathrm{X}$ & $\mathrm{X}$ & - & $\mathrm{X}$ \\
\hline P. viridiformis var. minor & - & - & - & - & - & - & - & $\mathrm{X}$ \\
\hline $\begin{array}{l}\text { Chamaepinnularia } \\
\text { brasilianopsis }\end{array}$ & - & - & - & - & - & - & $\mathrm{X}$ & - \\
\hline Capartogramma crucicula & $\mathrm{X}$ & - & - & - & - & - & - & - \\
\hline Stauroneis neohyalina & - & - & $\mathrm{x}$ & - & - & $\mathrm{X}$ & - & $\mathrm{x}$ \\
\hline S. gracilis & - & - & - & - & - & - & $\mathrm{X}$ & - \\
\hline S. phoenicenteron & - & - & $\mathrm{x}$ & $\mathrm{X}$ & - & - & $\mathrm{X}$ & - \\
\hline Craticula acidoclinata & - & - & - & - & - & - & $\mathrm{X}$ & - \\
\hline C. riparia var. mollenhaurei & - & - & - & - & - & - & $\mathrm{X}$ & - \\
\hline C. submolesta & - & - & - & - & - & - & $\mathrm{x}$ & - \\
\hline Nitzschia acidoclinata & - & - & $\mathrm{X}$ & $\mathrm{X}$ & $\mathrm{X}$ & - & - & $\mathrm{X}$ \\
\hline N. nana & - & - & - & - & $\mathrm{X}$ & - & - & - \\
\hline N. semirobusta & $\mathrm{X}$ & - & - & $\mathrm{X}$ & $\mathrm{X}$ & $\mathrm{X}$ & $\mathrm{X}$ & $\mathrm{X}$ \\
\hline Hantzschia amphyoxis & - & - & - & - & - & $\mathrm{X}$ & - & - \\
\hline $\begin{array}{l}\text { Rhopalodia gibberula var. } \\
\text { vanheurckii }\end{array}$ & - & - & - & - & - & - & - & $\mathrm{x}$ \\
\hline Surirella grunowii & $\mathrm{X}$ & - & - & - & - & - & $\mathrm{X}$ & - \\
\hline Iconella curvula & - & - & - & - & - & $\mathrm{X}$ & - & - \\
\hline Total of species & 30 & 18 & 34 & 31 & 42 & 35 & 49 & 41 \\
\hline
\end{tabular}




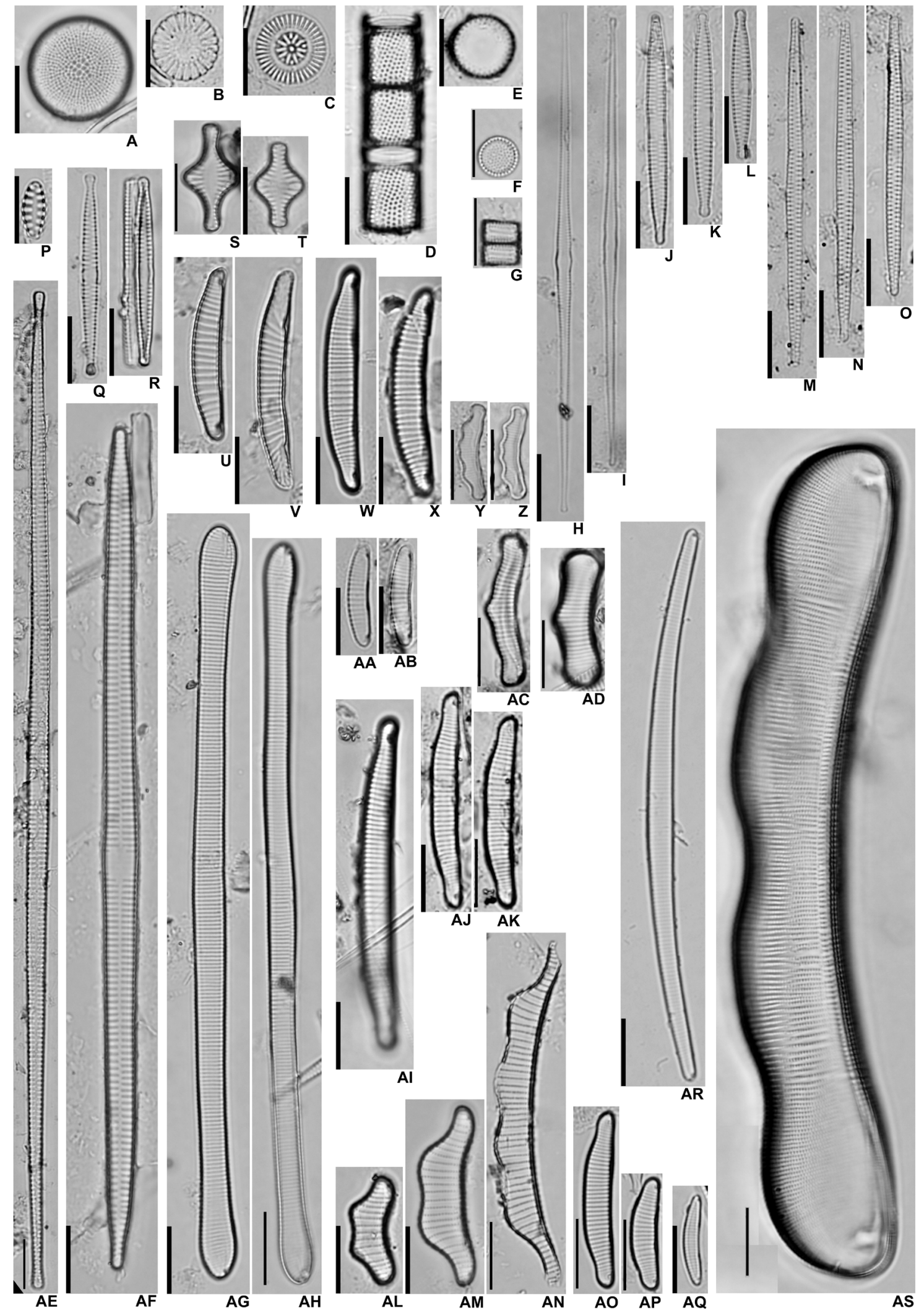

Figure 2. A. Spicaticribra kingstonii; B. Cyclotella meneghiniana; C. Discostella stelligera; D-E. Aulacoseira ambigua; F-G. Aulacoseira tenella; H-I. Fragilaria billingsii; J. Fragilaria capucina; K-L. Fragilaria recapitellata; M-O. Fragilaria tenera; P. Staurosirella pinnata; Q-R. Fragilaria sp., S-T. Staurosira construens; U-V. Eunotia parasiolii; W-X. Eunotia pseudosudetica; Y-Z. Eunotia paratridentula; AA-AB. Eunotia intermedia; AC. Eunotia pyramidata f. capitata; AD. Eunotia rabenhorstii var. monodon; AE. Ulnaria delicatissima; $\mathrm{AF}$. Ulnaria ulna; $\mathrm{AG}-\mathrm{AH}$. Eunotia desmogonioides; AI. Eunotia intricans; AJ-AK. Eunotia pseudoimplicata; AL-AN. Eunotia longicamelus; AO-AP. Eunotia minor; AQ. Eunotia subarcuatoides; AR. Eunotia naegelii; AS. Eunotia yanomami. 
Family AULACOSEIRACEAE

Aulacoseira ambigua (Grunow) Simonsen

Figures: 2D-2E

Valve diameter: 4-9.4 $\mu \mathrm{m}$; striae: 8 -17 in $10 \mu \mathrm{m}$; areolae: 8 -17 in $10 \mu \mathrm{m}$. Ecology: this species has a wide ecological tolerance, registered in oligotrophic (Stenger-Kovács et al. 2007), mesotrophic (Bicudo et al. 2016) and meso-eutrophic (Gómez \& Licursi 2001, Ivanov \& Kirilova 2004, Dela-Cruz et al. 2006) environments. In our samples, it occurred in slightly acid to circumneutral $\mathrm{pH}$ (6-6.85), low conductivity (24-24.5 $\mu \mathrm{S} \mathrm{cm-1)}$ and oligotrophic conditions.

Occurrence in samples: artificial (UPCB 63371; UPCB 63373; UPCB 63374) and natural (UPCB 63375; UPCB 63376; UPCB 63377; UPCB 63378) substrates.

Aulacoseira tenella (Nygaard) Simonsen

Figures: $2 \mathrm{~F}-2 \mathrm{G}$

Valve diameter: 6.3-8 $\mu \mathrm{m}$; striae: 15 in $10 \mu \mathrm{m}$.

Ecology: common in oligotrophic to mesotrophic environments (Bicudo et al. 2016, Siver \& Kling 1997). In our samples, it occurred in slightly acid to circumneutral $\mathrm{pH}(6-6.85)$, low conductivity $\left(24-24.5 \mu \mathrm{S} \mathrm{cm}-{ }^{1}\right)$ and oligotrophic conditions.

Occurrence in samples: artificial (UPCB 63373; UPCB 63374) and natural (UPCB 63375; UPCB 63376; UPCB 63377; UPCB 63378) substrates.

Family FRAGILARIOPHYCEAE

Fragilaria billingsii Wengrat, Wetzel \& Morales

Figures: $2 \mathrm{H}-2 \mathrm{I}$

Length: $66-73.6 \mu \mathrm{m}$; width (central region): $2-2.3 \mu \mathrm{m}$; striae: 22 in $10 \mu \mathrm{m}$.

Fragilaria billingsii is characterized by long and narrow valves with a bilaterally inflated central area. The striae are distinct and the specimes found in the present study have a higher striae density than those registered by Wengrat et al. (2016) (striae 17-20 in $10 \mu \mathrm{m}$ ).

Ecology: previously registered only for meso-eutrophic environments, with slightly acid $\mathrm{pH}$ and low conductivity (Wengrat et al. 2016) In our samples, it occurred in slightly acid to circumneutral $\mathrm{pH}$ (6-6.85), low conductivity (24-24.5 $\left.\mu \mathrm{S} \mathrm{cm}^{-1}\right)$ and oligotrophic conditions.

This is the first record for Paraná state.

Occurrence in samples: artificial (UPCB 63371; UPCB 63372; UPCB 63373; UPCB 63374) and natural (UPCB 63375; UPCB 63376; UPCB 63377; UPCB 63378) substrates.

\section{Fragilaria capucina Desmazières}

Figure: 2J

Length: 27-34.2 $\mu \mathrm{m}$; width: 2.8-2.9 $\mu \mathrm{m}$; striae: $15-16$ in $10 \mu \mathrm{m}$.

The taxonomy of Fragilaria capucina is very confusing. Based on the type materials, there are three different morphotypes of $F$. capucina documented in the literature. One of the morphotypes has lanceolate valves; the second one has linear to lanceolate valves that are shorter than in the other two morphotypes, and the third one has a linear valve with a rhombic central area and slightly rostrate valve ends (Tuji \& William 2006, Krammer \& Lange-Bertalot 1991a).

Ecology: probably cosmopolitan, found in oligo-mesotrophic (Delgado et al. 2015) to mesotrophic (vam Dam et al. 1994) and eutrophic environments (Hofmann 1994). Considered as a planktonic, benthic and terrestrial species (Delgado et al. 2015). In our samples, it occurred attached to artificial substrates and macrophytes, in slightly acid to circumneutral $\mathrm{pH}$ (6-6.75), low conductivity $\left(24-24.5 \mu \mathrm{S} \mathrm{cm}{ }^{-1}\right)$ and oligotrophic conditions.

Occurrence in samples: artificial (UPCB 63372; UPCB 63373; UPCB 63374) and natural (UPCB 63376; UPCB 63377; UPCB 63378) substrates.

Fragilaria recapitellata Lange-Bertalot \& Metzeltin Figures: $2 \mathrm{~K}-2 \mathrm{~L}$

Length: $22.2-30.4 \mu \mathrm{m}$; width: $2-4 \mu \mathrm{m}$; striae: $16-18$ in $10 \mu \mathrm{m}$.

This species has lanceolate valves with capitate ends and a unilateral central area (Metzeltin et al. 2009).

Ecology: this species is fairly common in alpha-mesosaprobic and eutrophic conditions (Cantonati et al. 2017, van Dam et al. 1994). In contrast to previous studies, it was common in our samples, indicating a tolerance to oligotrophic waters, poor in nutrients, with slightly acid to circumneutral $\mathrm{pH}(6-6.85)$, and low conductivity $\left(24-24.5 \mu \mathrm{S} \mathrm{cm}^{-1}\right)$. Although it is cosmopolitan and often present in periphyton samples from lakes, rivers, and streams of temperate regions (Delgado et al. 2015), it is rarely found in tropical regions (Silva et al. 2010, Tremarin et al. 2009).

Occurrence in samples: artificial (UPCB 63371; UPCB 63372; UPCB 63373; UPCB 63374) and natural (UPCB 63375; UPCB 63378) substrates.

Fragilaria tenera (W. Smith) Lange-Bertalot

Figures: $2 \mathrm{M}-2 \mathrm{O}$

Length: 38.8-51.8 $\mu \mathrm{m}$; width: 2.3-2.8 $\mu \mathrm{m}$; striae: 15 in $10 \mu \mathrm{m}$.

The specimens analyzed in the present study are shorter, with a lower striae density, and the absence of a central area. Hofmann et al. (2013) referred specimens of 30-100 $\mu \mathrm{m}$ long, 2-3 $\mu \mathrm{m}$ wide and with a striae density of 17-20 in $10 \mu \mathrm{m}$, and the often absence of a central area.

Ecology: this species was registered for oligo-mesotrophic environments (van Dam et al. 1994). In our samples it occurred attached to the substrates in slightly acid to circumneutral $\mathrm{pH}$ (6-6.85), low conductivity (24-24.5 $\left.\mu \mathrm{S} \mathrm{cm}^{-1}\right)$ and oligotrophic conditions.

Occurrence in samples: artificial (UPCB 63371; UPCB 63372; UPCB 63373; UPCB 63374) and natural (UPCB 63376; UPCB 63377) substrates.

Fragilaria sp.

Figures: 2Q-2R

Length: $24.5-31.7 \mu \mathrm{m}$; width: 2.3-3.1 $\mu \mathrm{m}$; striae: $16-17$ in $10 \mu \mathrm{m}$.

Fragilaria sp. resembles Fragilaria austriaca (Grunow) Lange-Bertalot in the outline but has wider valves (3-4 $\mu \mathrm{m})$ and a lower striae density (12-15 $\mu \mathrm{m})$. Fragilaria pararumpens Lange-Bertalot, Hofmann \& Werum has similar dimensions to Fragilaria sp., but a more lanceolate valve with subcapitate ends (Cantonati et al. 2017).

Ecology: In our samples, it occurred only in temperatures $<21^{\circ} \mathrm{C}$, slightly acid to circumneutral $\mathrm{pH}(6-6.75)$, low conductivity (22.5-24.5 $\mu \mathrm{S} \mathrm{cm}^{-1}$ ) and oligotrophic conditions.

Occurrence in samples: artificial (UPCB 63371; UPCB 63373; UPCB 63374) and natural (UPCB 63378) substrates. 
Family STAUROSIRACEAE

Staurosira construens Ehrenberg

Figures: 2S-2T

Length: $15.7 \mu \mathrm{m}$; width: $8.6 \mu \mathrm{m}$; striae: 18 in $10 \mu \mathrm{m}$.

Ecology: this species is registered for meso-eutrophic environments (van Dam et al. 1994) and is considered as tolerant to different water conditions (Hofmann 1994). In our samples, it occurred in slighltly acid $\mathrm{pH}$ (6), low conductivity $\left(24.5 \mu \mathrm{S} \mathrm{cm}-^{-1}\right)$ and oligotrophic conditions, only in winter (temperature $16^{\circ} \mathrm{C}$ ).

Occurrence in samples: natural substrates (UPCB 63378).

Staurosirella pinnata (Ehrenberg) Williams \& Round.

Figure: $2 \mathrm{P}$

Length: $8-14.4 \mu \mathrm{m}$; width: 3.3-3.8 $\mu \mathrm{m}$; striae: $8-11$ in $10 \mu \mathrm{m}$.

Ecology: this species is considered as tolerant (Hofmann 1994) to indifferent (van Dam et al. 1994) to the trophic state. In our samples, it occurred in slighltly acid $\mathrm{pH}(6)$, low conductivity $\left(24.5 \mu \mathrm{S} \mathrm{cm}^{-1}\right)$ and oligotrophic condition, only in winter (temperature $16^{\circ} \mathrm{C}$ ).

Occurrence in samples: artificial substrates (UPCB 63374).

\section{Family ULNARIACEAE}

Ulnaria delicatissima (Smith) Aboal \& Silva

Figure: $2 \mathrm{AE}$

Length: 62.4-109.5 $\mu \mathrm{m}$; width: 2.4-4.7 $\mu \mathrm{m}$; striae: $13-16$ in $10 \mu \mathrm{m}$.

Ecology: common in oligo-mesotrophic environments (van Dam et al. 1994, Hofmann 1994). In our samples, it occurred in slighltly acid to circumneutral $\mathrm{pH}(6-6.85)$, low conductivity $\left(24-24.5 \mu \mathrm{S} \mathrm{cm}^{-1}\right)$ and oligotrophic conditions.

Occurrence in samples: artificial (UPCB 63371; UPCB 63372; UPCB 63374) and natural (UPCB 63375; UPCB 63378) substrates.

\section{Ulnaria ulna (Nitzsch) Compère.}

Figure: $2 \mathrm{AF}$

Length: $90-189 \mu \mathrm{m}$; width: 4-4.8 $\mu \mathrm{m}$; striae: 9-14 in $10 \mu \mathrm{m}$.

Ecology: considered as indifferent to tolerant to the trophic state of the environment (van Dam et al. 1994, Hofmann 1994). In our samples, it occurred in circumneutral $\mathrm{pH}(6.75)$, low conductivity $\left(24.5 \mu \mathrm{S} \mathrm{cm}-^{1}\right)$ and oligotrophic conditions, only in summer (temperature of $27^{\circ} \mathrm{C}$ and accumulated rainfall $326.9 \mathrm{~mm}$ ).

Occurrence in samples: natural substrates (UPCB 63376).

\section{Family EUNOTIACEAE}

Eunotia desmogonioides Metzeltin \& Lange-Bertalot

Figures: $2 \mathrm{AG}-2 \mathrm{AH}$

Length: $99-159.3 \mu \mathrm{m}$; width: $3.5-5 \mu \mathrm{m}$; striae: $17-20$ in $10 \mu \mathrm{m}$.

This species has a valve outline similar to Eunotia flexuosa (Brébisson) Kützing, although with narrower valves and a higher striae density. Eunotia rabenhorstiana var. elongata (Patrick) Metzeltin \& LangeBertalot is similar to E. flexuosa but has wider valves with more inflated ends (Costa et al. 2017).

Ecology: previously registered for Brazilian oligo- to mesotrophic reservoirs, with low conductivity and slightly acidic to neutral $\mathrm{pH}$ (Costa et al. 2017). In our samples, it occurred in slightly acid to circumneutral $\mathrm{pH}$ (6-6.85), low conductivity $\left(22.5-24.5 \mu \mathrm{S} \mathrm{cm}^{-1}\right)$ and oligotrophic conditions.
Occurrence in samples: artificial (UPCB 63371, UPCB 63372, UPCB 63373) and natural (UPCB 63375, UPCB 63376, UPCB 63377, UPCB 63378) substrates.

Eunotia intermedia (Krasske ex Hustedt) Nörpel \& Lange-Bertalot Figures: 2AA-2AB

Length: 13.3-16.8 $\mu \mathrm{m}$; width: $3.1-3.3 \mu \mathrm{m}$; striae: $14-15$ in $10 \mu \mathrm{m}$.

Ecology: previously registered for slightly acidic waters with low conductivity (Lange-Bertalot et al. 2011). In our samples, it occurred in circumneutral $\mathrm{pH}(6.85)$, low conductivity $\left(24 \mu \mathrm{S} \mathrm{cm}-{ }^{-1}\right)$ and oligotrophic conditions, only in spring (temperature $<21^{\circ} \mathrm{C}$ ).

Occurrence in samples: artificial substrate (UPCB 63371).

Eunotia intricans Lange-Bertalot \& Metzeltin

Figure: 2AI

Length: $35-51.7 \mu \mathrm{m}$; width: 4.5-5.1 $\mu \mathrm{m}$; striae: $11-13$ in $10 \mu \mathrm{m}$.

Eunotia intricans is similar to Eunotia parasiolii Metzeltin \& LangeBertalot in the valve outline, although it has a lower striae density (6.5-11/10 $\mu \mathrm{m}$, according to Metzeltin \& Lange-Bertalot 1998). In Piraquara reservoir, the specimens were longer than the type specimen (17-48 $\mu \mathrm{m}$, according to Lange-Bertalot \& Metzeltin 2009), but have a similar length to other specimens registered in Brazilian reservoirs (Costa et al. 2017).

Ecology: previously registered for oligo-mesotrophic environments, with a preference for acid waters with low conductivity (Costa et al. 2017). In our samples, it occurred in circumneutral $\mathrm{pH}$ (6.7-6.85), low conductivity (22.5-24 $\left.\mu \mathrm{S} \mathrm{cm}^{-1}\right)$ and oligotrophic conditions, in spring and autumn (temperature $<21^{\circ} \mathrm{C}$ ).

Occurrence in samples: natural substrates (UPCB 63375, 63377).

Eunotia longicamelus Costa, Bicudo \& Wetzel

Figure: $2 \mathrm{AL}-2 \mathrm{AN}$

Length: 16.2-52.6 $\mu \mathrm{m}$; width: 5.4-5.26 $\mu \mathrm{m}$; striae: 11 in $10 \mu \mathrm{m}$; valvar undulations: $2-4$.

Similar to Eunotia camelus Ehrenberg, but differs in the type and number of undulations on the dorsal margin (two undulations subdivided into two more) and the presence of wider valves (length: $22-30 \mu \mathrm{m}$; width: 6-8.8 $\mu \mathrm{m}$; striae density 8-12 in $10 \mu \mathrm{m}$ and two undulations) (Costa et al. 2017, Reichardt 1995).

Ecology: previously registered for mesotrophic environments, with a preference for slightly acidic waters ( $\mathrm{pH}$ 6.6) with medium values of conductivity $\left(71 \mu \mathrm{S} \mathrm{cm}^{-1}\right)$ (Costa et al. 2017). In our samples, it occurred only in winter (temperature $16^{\circ} \mathrm{C}$ ) and expanded the occurrence to oligotrophic environments with slightly acid $\mathrm{pH}$ (6), and low conductivity $\left(24.5 \mu \mathrm{S} \mathrm{cm}^{-1}\right)$.

This is the first record for Paraná state.

Occurrence in samples: natural substrates (UPCB 63378).

Eunotia minor (Kützing) Grunow.

Figures: 2AO-2AP

Length: $17-24.7 \mu \mathrm{m}$; width: $3.8 \mu \mathrm{m}$; striae: $17-18$ in $10 \mu \mathrm{m}$.

Ecology: considered as tolerant to different trophic states, ranging from oligo- to eutrophic (van Dam et al. 1994, Hofmann 1994). In our samples, it occurred in slightly acid $\mathrm{pH}(6)$, low conductivity $(24.5 \mu \mathrm{S}$ $\mathrm{cm}^{-1}$ ) and oligotrophic conditions, only in winter (temperature $16^{\circ} \mathrm{C}$ ).

Occurrence in samples: natural substrates (UPCB 63378). 
Eunotia naegelii Migula.

Figure: 2AR

Length: $40-48.4 \mu \mathrm{m}$; width: $1.8-3 \mu \mathrm{m}$; striae: $21-24$ in $10 \mu \mathrm{m}$.

Ecology: considered as acidophile; registered for ultra-oligotrophic to oligotrophic environments (Costa et al. 2017, van Dam et al. 1994). In our samples, it occurred in slightly acid pH (6), low conductivity (24.5 $\mu \mathrm{S} \mathrm{cm}^{-1}$ ) and oligotrophic conditions, only in winter (temperature $16^{\circ} \mathrm{C}$ ).

Occurrence in samples: natural substrates (UPCB 63378).

Eunotia parasiolii Metzeltin \& Lange-Bertalot.

Figures: 2U-2V

Length: 18.5-32.6 $\mu \mathrm{m}$; width: 3-4.7 $\mu \mathrm{m}$; striae: 9-12 in $10 \mu \mathrm{m}$.

Ecology: previously registered for acidic waters ( $\mathrm{pH}$ 4.4-5.3) with a low conductivity (9.4-12.6 $\mu \mathrm{S} \mathrm{cm}^{-1}$ ) (Ferrari et al. 2007) to slightly acidic (pH 6.6-6.8) and oligotrophic environments (Costa et al. 2017). In our samples, it occurred in circumneutral $\mathrm{pH}(6.85)$, low conductivity $(24 \mu \mathrm{S}$ $\mathrm{cm}^{-1}$ ) and oligotrophic conditions, only in spring (temperature $<21^{\circ} \mathrm{C}$ ).

Occurrence in samples: natural substrates (UPCB 63375).

Eunotia paratridentula Lange-Bertalot \& Kulikovskyi.

Figures: $2 \mathrm{Y}-2 \mathrm{Z}$

Length: $13-17.6 \mu \mathrm{m}$; width: $2.8-4 \mu \mathrm{m}$; striae: $14-16$ in $10 \mu \mathrm{m}$; undulations: $3-4$.

Previously reported for Paraná State as Eunotia muscicola Krasske var. tridentula Nörpel \& Lange-Bertalot (Tremarin et al. 2009). It differs from E. muscicola Krasske by the lower striae density; and from $E$. paramuscicola Krstić, Levkov \& Pavlov by the broadly protracted apices (Krstić et al. 2013).

Ecology: considered as acidophile (van Dam et al. 1994); registered for mesotrophic environments (Marra et al. 2016). Our study expanded its occurrence to environments with $\mathrm{pH}$ ranging from slightly acid to circumneutral (6-6.85), low conductivity $\left(22.5-24.5 \mu \mathrm{S} \mathrm{cm}^{-1}\right)$ and oligotrophic conditions.

Occurrence in samples: artificial (UPCB 63371; UPCB 63373) and natural (UPCB 63375; UPCB 63376; UPCB 63378) substrates.

\section{Eunotia pseudoimplicata Lange-Bertalot, Costa \& Wetzel}

Figures: 2AJ-2AK

Length: $28.7-43 \mu \mathrm{m}$; width: $4.2-5.3 \mu \mathrm{m}$; striae: $14-16$ in $10 \mu \mathrm{m}$.

Ecology: oligo-mesotrophic reservoirs, with slightly acid to neutral waters (Costa et al. 2017). In our samples, it occurred in circumneutral $\mathrm{pH}$ (6.85), low conductivity $\left(24 \mu \mathrm{S} \mathrm{cm}^{-1}\right)$ and oligotrophic conditions, only in spring (temperature $<21^{\circ} \mathrm{C}$ ).

This is the first record for Paraná state.

Occurrence in samples: artificial (UPCB 63371) and natural (UPCB 63375) substrates.

Eunotia pseudosudetica Metzeltin, Lange-Bertalot \& García-Rodríguez Figures: 2W-2X

Length: 30.4-33.26 $\mu \mathrm{m}$; width: 4.9-5.4 $\mu \mathrm{m}$; striae: 12 in $10 \mu \mathrm{m}$.

Ecology: this species occurred in slightly acidic to circumneutral $\mathrm{pH}$ (6-6.85), low conductivity (22.5-24 $\left.\mu \mathrm{S} \mathrm{cm}^{-1}\right)$ and in oligotrophic conditions, in agreement with previously studies (Costa et al. 2017), but can also be registered for nutrient-rich environments (Bertolli et al. 2010, Faria et al. 2010, Marra et al. 2016). Usually found in the periphyton, but can be also registered from phytoplankton (Bartozek et al. 2013) and surface sediments (Costa et al. 2017).

Occurrence in samples: artificial (UPCB 63371; UPCB 63372; UPCB 63373) and natural (UPCB 63375; UPCB 63376; UPCB 63377; UPCB 63378) substrates.

\section{Eunotia pyramidata f. capitata Krasske}

Figure: $2 \mathrm{AC}$

Length: $25.5 \mu \mathrm{m}$; width: $4.6 \mu \mathrm{m}$; striae: 15 in $10 \mu \mathrm{m}$; undulations: 3 . It differs from Eunotia rabenhorstii var. triodon Cleve \& Grunow by the presence of a more pronounced mark in the central undulation (Costa et al. 2017).

Ecology: previously registered for moody pools with sphagnum moss (Krasske 1948), and from samples of surface sediments collected in environments with acid $\mathrm{pH}$ and poor in nutrients (Costa et al. 2017). In our samples, it occurred in circumneutral $\mathrm{pH}$ (6.7), low conductivity $\left(22.5 \mu \mathrm{S} \mathrm{cm}^{-1}\right)$ and oligotrophic conditions, only in autumn (temperature $\left.18.6^{\circ} \mathrm{C}\right)$.

Occurrence in samples: natural substrates (UPCB 63377).

\section{Eunotia rabenhorstii var. monodon Cleve \& Grunow}

Figure: 2AD

Length: $20 \mu \mathrm{m}$; width: $6.2 \mu \mathrm{m}$; striae: 17 in $10 \mu \mathrm{m}$.

Ecology: previously registered for a mesotrophic reservoir in Paraná state (Bertolli et al. 2010, Marra et al. 2016) and for ultraoligotrophic to eutrophic reservoirs with slightly acidic to alkaline waters ( $\mathrm{pH}$ 6.27.3) in São Paulo state (Costa et al. 2017). In our samples, it occurred in circumneutral $\mathrm{pH}$ (6.7-6.75), low conductivity $(22.5-24.5 \mu \mathrm{S} \mathrm{cm}-1)$ and oligotrophic conditions, in summer and autumn (temperature from $18.6-27^{\circ} \mathrm{C}$ ).

Occurrence in samples: natural substrates (UPCB 63376; UPCB 63377).

Eunotia subarcuatoides Alles, Nörpel \& Lange-Bertalot

Figure: $2 \mathrm{AQ}$

Length: $13.5-17.3 \mu \mathrm{m}$; width: $2.4-2.9 \mu \mathrm{m}$; striae: $23-24$ in $10 \mu \mathrm{m}$. Similar to the small forms of Eunotia bilunaris (Ehrenberg) Schaarschmidt, but with a lower density of striae (13-17 in $10 \mu \mathrm{m})$ that are less conspicuous (Costa et al. 2017). The specimens found herein presented a less width than the type material (3-4.5 $\mu \mathrm{m}$, according to Alles et al. 1991), but presented a similar width to the specimens (2.5-3.3 $\mu \mathrm{m}$ ) registered by Costa et al. (2017) in Brazilian reservoirs.

Ecology: considered as acidobiontic (van Dam et al. 1994). In Brazil, it was previously registered for ultraoligo to eutrophic conditions (Costa et al. 2017, Silva et al. 2010), with acid to alkaline $\mathrm{pH}$ (Costa et al. 2017). In our samples, it occurred in slightly acid to circumneutral $\mathrm{pH}(6-6.85)$, low conductivity (22.5-24.5 $\left.\mu \mathrm{S} \mathrm{cm}^{-1}\right)$ and oligotrophic conditions.

Occurrence in samples: natural substrates (UPCB 63375; UPCB 63376; UPCB 63377; UPCB 63378).

Eunotia yanomami Metzeltin \& Lange-Bertalot

Figure: $2 \mathrm{AS}$

Length: $120 \mu \mathrm{m}$; width: $13.5 \mu \mathrm{m}$; striae: 15 in $10 \mu \mathrm{m}$; undulations: 4 . Similar to Eunotia zygodon Ehrenberg in the valve outline, but $E$. zygodon has a smaller size (less than $55 \mu \mathrm{m}$ in length, according to Metzeltin \& Lange-Bertalot 1998). 
Ecology: previously registered for oligotrophic to mesotrophic environments (Marra et al. 2016, Costa et al. 2017), with slightly acid waters (pH 5.4-6.4) and low to medium conductivity (12-70 $\mu \mathrm{S} \mathrm{cm}^{-1}$ ) (Bicca \& Torgan 2009). In our samples, it occurred in circumneutral $\mathrm{pH}$ (6.7), low conductivity $\left(22.5 \mu \mathrm{S} \mathrm{cm}^{-1}\right)$ and oligotrophic conditions, only in autumn (temperature $18.6^{\circ} \mathrm{C}$ ).

Occurrence in samples: natural substrates (UPCB 63377).

\section{Family GOMPHONEMATACEAE}

Placoneis elginensis (Gregory) Cox

Figure: $3 \mathrm{~A}$

Length: $34.7 \mu \mathrm{m}$; width: $10 \mu \mathrm{m}$; striae: 13 in $10 \mu \mathrm{m}$.

Ecology: previously registered for highly alkaline waters, and for mesotrophic and eutrophic environments (van Dam et al. 1994, Hofmann 1994, Poulíčková et al. 2008). In our samples, it occurred in circumneutral $\mathrm{pH}(6.7)$, low conductivity $\left(22.5 \mu \mathrm{S} \mathrm{cm}^{-1}\right)$ and oligotrophic conditions, only in autumn (temperature $18.6^{\circ} \mathrm{C}$ ).

Occurrence in samples: artificial substrates (UPCB 63373).

\section{Encyonema neogracile Krammer.}

Figures: 3B-3C

Length: $35.5-56.6 \mu \mathrm{m}$; width: 6.5-7.5 $\mu \mathrm{m}$; dorsal striae: 14 in $10 \mu \mathrm{m}$; ventral striae: $15-16$ in $10 \mu \mathrm{m}$.

Ecology: this species was frequent in our samples and occurred in slightly acid to circumneutral $\mathrm{pH}$ (6-6.85), low conductivity (22.5-24.5 $\mu \mathrm{S} \mathrm{cm}^{-1}$ ) and oligotrophic conditions, but was also previously registered for oligo-mesotrophic and mesotrophic environments (van Dam et al. 1994, Marra et al. 2016).

Occurrence in samples: artificial (UPCB 63371; UPCB 63372; UPCB 63373; UPCB 63374) and natural (UPCB 63375; UPCB 63376; UPCB 63377; UPCB 63378) substrates.

\section{Encyonema silesiacum (Bleisch) Mann.}

Figure: 3D

Length: $17.4-21.5 \mu \mathrm{m}$; width: 5-7.5 $\mu \mathrm{m}$; dorsal striae: $11-17$ in $10 \mu \mathrm{m}$; ventral striae: $12-16$ in $10 \mu \mathrm{m}$.

Ecology: widely distributed, considered as a circumneutral species (van Dam et al. 1994), occurring in waters ranging from oligo to eutrophic (van Dam et al. 1994, Hofmann 1994, Bertolli et al. 2010, Silva et al. 2010, Marra et al. 2016). This study expands its occurrence to slightly acid $\mathrm{pH}$ (6-6.85), low conductivity $\left(24-24.5 \mu \mathrm{S} \mathrm{cm}^{-1}\right)$ and oligotrophic conditions.

Occurrence in samples: artificial (UPCB 6371) and natural (UPCB 63375; UPCB 63376; UPCB 63378) substrates.

\section{Encyonopsis cf. reichardtii Krammer}

Figures: 3Q-3S

Length: $36.5-40 \mu \mathrm{m}$; width: $5.8-6 \mu \mathrm{m}$; maximum ratio $\mathrm{L} / \mathrm{W}=6.8$; dorsal striae: $18-20$ in $10 \mu \mathrm{m}$; ventral striae: $17-21$ in $10 \mu \mathrm{m}$.

The specimens from Piraquara I reservoir presented the valve outline, striation pattern, and isolated punctum near the central striae similar to Encyonopsis reichardtii Krammer. As the type specimens have a slightly more rhombo-lanceolate contour, wider valves $(7-7.7 \mu \mathrm{m})$ and a maximum ratio L/W of 6.1 (Krammer 1997b: 131) we preferred to identify the taxon as conferatum.
Ecology: this species occurred in slightly acid to circumneutral $\mathrm{pH}$ (6$6.75)$, low conductivity $\left(22.5-24.5 \mu \mathrm{S} \mathrm{cm}^{-1}\right)$ and oligotrophic conditions. Occurrence in samples: artificial (UPCB 63372; UPCB 63373) and natural (UPCB 63376; UPCB 63377; UPCB 63378) substrates.

\section{Encyonopsis schubartii (Hustedt) Krammer}

Figure: 3E

Length: 29.5-33.6 $\mu \mathrm{m}$; width: 6-6.4 $\mu \mathrm{m}$; dorsal striae: 9-11 in $10 \mu \mathrm{m}$; ventral striae: $9-12$ in $10 \mu \mathrm{m}$.

Ecology: previously registered for oligotrophic (Krammer 1997b), and mesotrophic environments, with acid pH (Wengrat et al. 2015). In our samples, it occurred in circumneutral $\mathrm{pH}$ (6.7-6.85), low conductivity (22.5-24.5 $\left.\mu \mathrm{S} \mathrm{cm}^{-1}\right)$ and oligotrophic conditions.

Occurrence in samples: artificial (UPCB 63371; UPCB 63372; UPCB 63373) and natural (UPCB 63375; UPCB 63377) substrates.

Encyonopsis subminuta Krammer \& Reichardt.

Figure: $3 \mathrm{~F}$

Length: 15.3-21.3 $\mu \mathrm{m}$; width: 3.7-4.8 $\mu \mathrm{m}$; striae: 26 in $10 \mu \mathrm{m}$.

Ecology: common in oligo- and mesotrophic environments, and rare in electrolyte-poor environments (Bertolli et al. 2010, Cantonati et al. 2017). In our samples, it occurred in circumneutral $\mathrm{pH}$ (6.85), low conductivity $\left(24 \mu \mathrm{S} \mathrm{cm}^{-1}\right)$ and oligotrophic conditions, only in spring (temperature $20.8^{\circ} \mathrm{C}$ ).

Occurrence in samples: artificial substrate (UPCB 63371).

Gomphonema gracile Ehrenberg

Figure: $3 \mathrm{~J}-3 \mathrm{~K}$

Length: $28-43 \mu \mathrm{m}$; width: 5.8-7.2 $\mu \mathrm{m}$; striae: 14-16 in $10 \mu \mathrm{m}$.

The Gomphonema gracile species-complex includes representatives with valves of diverse forms, sizes and measures. Gomphonema naviculoides Smith is very similar to G. gracile in the valve outline and striae density, but they differ in the width range, being of $4.2-9 \mu \mathrm{m}$ in G. gracile and of 7.8-9.5 $\mu \mathrm{m}$ in G. naviculoides (Reichardt 2015a). Ecology: typical of environments with low conductivity and nutrients (Krammer \& Lange-Bertalot 1986). It occurred in all our samples, in slightly acid to circumneutral $\mathrm{pH}$ (6-6.85), low conductivity (22.5-24.5 $\mu \mathrm{S} \mathrm{cm}^{-1}$ ) and oligotrophic conditions.

Occurrence in samples: artificial (UPCB 63371; UPCB 63372; UPCB 63373; UPCB 63374) and natural (UPCB 63375; UPCB 63376; UPCB 63377; UPCB 63378) substrates.

\section{Gomphonema lagenula Kützing}

Figures: $3 \mathrm{~L}-3 \mathrm{M}$

Length: $17.2-21.7 \mu \mathrm{m}$; width: 4.5-4.8 $\mu \mathrm{m}$; striae: $18-19$ in $10 \mu \mathrm{m}$

Ecology: considered as tolerant (Hofmann 1994), this species is widely distributed in environments ranging from oligotrophic to hypereutrophic (Bertolli, et al. 2010, Silva et al. 2010, Faria et al. 2010, Marra et al. 2016, Bartozek et al. 2018). In our samples, it occurred in slightly acid to circumneutral $\mathrm{pH}(6-6.7)$, low conductivity $\left(22.5-24.5 \mu \mathrm{S} \mathrm{cm}^{-1}\right)$ and oligotrophic conditions, in autumn and winter (temperature $<19^{\circ} \mathrm{C}$ ). Occurrence in samples: natural substrates (UPCB 63377; UPCB 63378). 
Silva-Lehmkuhl, A.M. et al.
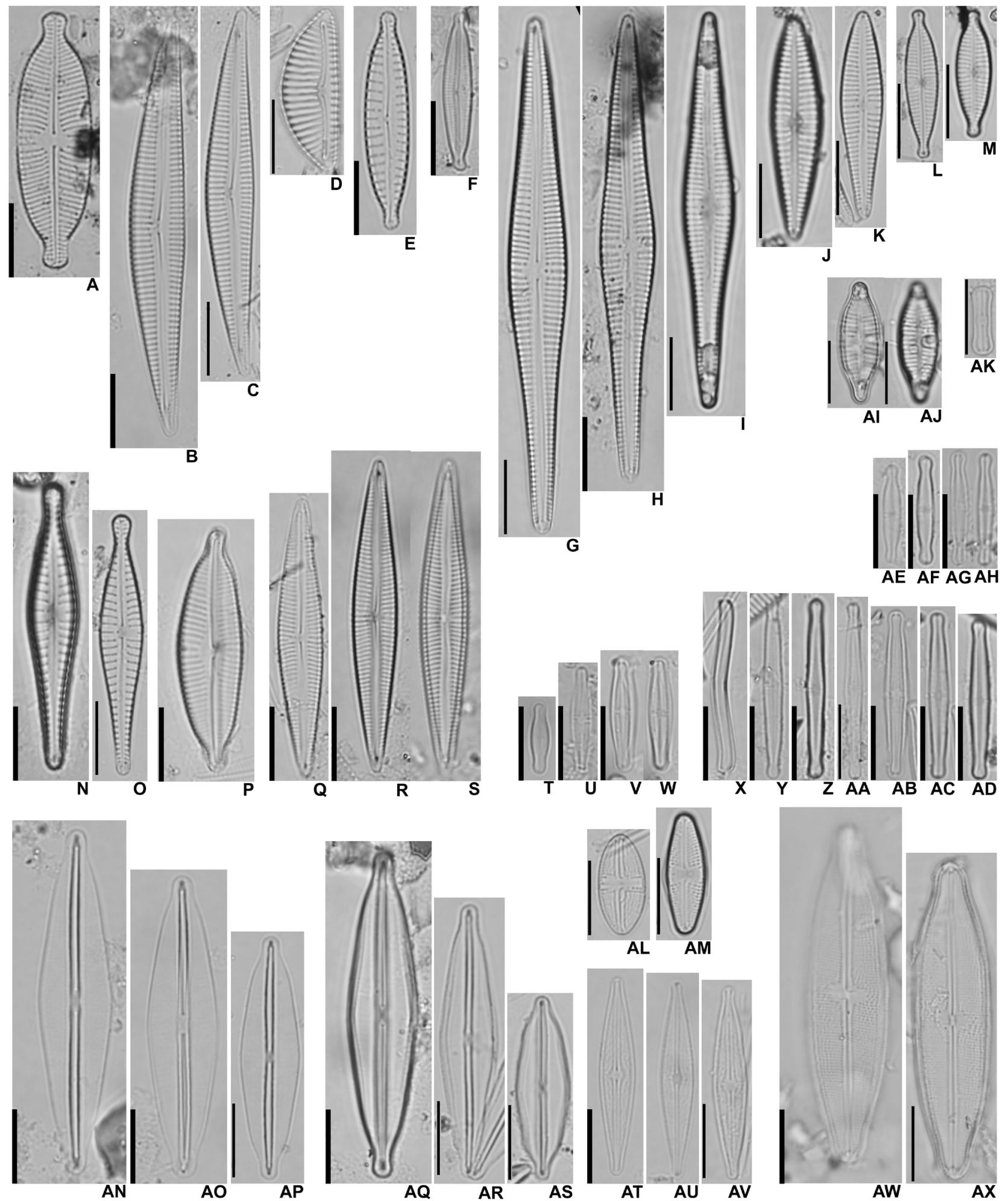

Figure 3. A. Placoneis elginensis; B-C. Encyonema neogracile; D. Encyonema silesiacum; E. Encyonopsis schubartii; F. Encyonopsis subminuta; G-I. Gomphonema spiculoides; J-K. Gomphonema gracile; L-M. Gomphonema lagenula; N-O. Gomphonema pantropicum; P. Cymbopleura naviculiformis; Q-S. Encyonopsis cf. reichardtii; T-W. Achnanthidium minutissimum; X-AD. Achnanthidium neomicrocephalum; AE-AH. Achnanthidium sp.; AI-AJ. Planothidium incuriatum; AK. Humidophila biscutella; AL. Luticola permuticoides; AM. Luticola simplex; AN-AP. Frustulia australocrassinervia; 3AQ-3AS. Frustulia undosa; AT-AV. Brachysira neoexilis; AW-AX. Neidium affine. 
Periphytic diatoms from an oligotrophic reservoir

Gomphonema pantropicum Reichardt

Figure: $3 \mathrm{~N}-3 \mathrm{O}$

Length: $35.2-38 \mu \mathrm{m}$; width: 6-6.3 $\mu \mathrm{m}$; striae: $10-11$ in $10 \mu \mathrm{m}$.

Valves lanceolate, with constricted round apices. Spaced and convergent striae towards the middle part of the valves and parallel to the apices. In Brazilian environments, Gomphonema pantropicum is often misidentified as Gomphonema subtile Ehrenberg (Osorio et al. 2017, Marra et al. 2016, Marquardt \& Bicudo 2014). Gomphonema subtile presents the valves with broadly capitate ends, a long and narrow "neck" and flatly-rounded apices (Reichardt 2015b).

Ecology: distributed in South America and in tropical Africa, India, and Southeast Asia (Reichardt 2015b); the ecology of this species is little known. In Brazil, it was previously registered from epiphytic samples in the North and South region (Medeiros et al. 2018, Azevedo et al. 2018). In our samples, it occurred in slightly acid pH (6), low conductivity $\left(24.5 \mu \mathrm{S} \mathrm{cm}^{-1}\right)$ and oligotrophic conditions, only in winter (temperature $16^{\circ} \mathrm{C}$ ).

Occurrence in samples: artificial substrates (UPCB 63374).

Gomphonema spiculoides Gandhi

Figures: 3G-3I

Length: 54.2-69 $\mu \mathrm{m}$; width: 7.3-8 $\mu \mathrm{m}$; striae: 14 in $10 \mu \mathrm{m}$.

This species presents valve ends clearly apiculate, a central area weakly delimited, a narrow axial area, undulate and lateral raphe, and striae slightly radiate.

The specimens recorded in the present study have striae slightly radiate and a less width than the specimens found by Karthick \& Kociolek (2012), resembling the Gandhi's original draw and description. Gomphonema spiculoides can be mistaken with large valves of Gomphonema gracile Ehrenberg.

Ecology: this species has a low tolerance to alkaline conditions and it was previously registered for oligotrophic and slightly acid waters (Riato et al. 2017). It occurred in all our samples, in slightly acid to circumneutral $\mathrm{pH}$ (6-6.85), low conductivity $\left(22.5-24.5 \mu \mathrm{S} \mathrm{cm} \mathrm{cm}^{-1}\right)$ and oligotrophic conditions.

This is the first record for Brazil.

Occurrence in samples: artificial (UPCB 63371; UPCB 63372; UPCB 63373; UPCB 63374) and natural (UPCB 63375; UPCB 63376; UPCB 63377; UPCB 63378) substrates.

\section{Family CYMBELLACEAE}

Cymbopleura naviculiformis (Auerswald) Krammer

Figure: 3P

Length: $32.1 \mu \mathrm{m}$; width: $9 \mu \mathrm{m}$; dorsal striae: 13 in $10 \mu \mathrm{m}$; ventral striae: 15 in $10 \mu \mathrm{m}$.

Ecology: previously registered for oligotrophic to eutrophic waters (Bertolli et al. 2010, Silva et al. 2010, Marra et al. 2016, Cantonati et al. 2017). In our samples, it occurred in circumneutral $\mathrm{pH}$ (6.85), low conductivity $\left(24 \mu \mathrm{S} \mathrm{cm}^{-1}\right)$ and oligotrophic conditions, only in spring (temperature $20.8^{\circ} \mathrm{C}$ ).

Occurrence in samples: natural substrates (UPCB 63375).

\section{Family ACHNANTHIDIACEAE}

Achnanthidium minutissimum (Kützing) Czarnecki

Figures: $3 \mathrm{~T}-3 \mathrm{~W}$

Length: 9.6-15.4 $\mu \mathrm{m}$; width: 2.6-2.8 $\mu \mathrm{m}$; indistinct striae.
Ecology: very wide range of ecological preferences (Cantonati et al. 2017). In our samples, it occurred in temperature $<21^{\circ} \mathrm{C}$, slightly acid to circumneutral $\mathrm{pH}(6-6.85)$, low conductivity $\left(22.5-24.5 \mu \mathrm{S} \mathrm{cm}^{-1}\right)$ and oligotrophic conditions.

Occurrence in samples: artificial (UPCB 63371; UPCB 63374) and natural (UPCB 63375; UPCB 63377; UPCB 63378) substrates.

\section{Achnanthidium neomicrocephalum Lange-Bertalot \& Staab} Figures: $3 \mathrm{X}-3 \mathrm{AD}$

Length: 21.6-25.3 $\mu \mathrm{m}$; width: 2.5-2.8 $\mu \mathrm{m}$; indistinct striae.

Valves linear-lanceolate with subcapitate apices. Axial area narrow. Central area variable in shape.

Achnanthidium neomicrocephalum has narrower valves than Achnanthidium gracillimum (Meister) Lange-Bertalot $(3.4-4.5 \mu \mathrm{m})$ and A. caledonicum (Lange-Bertalot) Lange-Bertalot $(2.7-3.8 \mu \mathrm{m})$. Achnanthidium caledonicum presents broader valve ends than $A$. neomicrocephalum.

Ecology: previously registered for oligotrophic environments, mainly springs and lakes (Cantonati et al. 2017, Cantonati \& Lange-Bertalot 2010). In our samples, it occurred in slightly acid $\mathrm{pH}$ (6) and low conductivity $\left(24.5 \mu \mathrm{S} \mathrm{cm}^{-1}\right)$, and oligotrophic condition, only in winter (temperature $16^{\circ} \mathrm{C}$ ).

This is the first record for Brazil

Occurrence in samples: artificial substrates (UPCB 63374).

\section{Achnanthidium sp.}

Figures: $3 \mathrm{AE}-3 \mathrm{AH}$

Length: 13.3-15.4 $\mu \mathrm{m}$; width: 2.4-2.5 $\mu \mathrm{m}$; indistinct striae.

Valves linear-lanceolate, with parallel margins and capitate apices. Narrow and linear axial area. Central area bordered by one striae on both sides. Resembles Achnanthidium tropicocatenatum Marquardt, Wetzel \& Ector although the central portion is not inflated (Marquard et al. 2017).

Ecology: this species was frequent in ours samples, and occurred in slightly acid to circumneutral $\mathrm{pH}$ (6-6.85), low conductivity (22.5-24.5 $\mu \mathrm{S} \mathrm{cm}^{-1}$ ) and oligotrophic conditions.

Occurrence in samples: artificial (UPCB 63371; UPCB 63373) and natural (UPCB 63375; UPCB 63376; UPCB 63377; UPCB 63378) substrates.

Planothidium incuriatum Wetzel, Van de Vijver \& Ector

Figures: 3AI-3AJ

Length: $20 \mu \mathrm{m}$; width: $7 \mu \mathrm{m}$; striae: 14 in $10 \mu \mathrm{m}$.

Planothidium incuriatum is widely reported in Brazil as P. biporomum (Hohn \& Hellerman) Lange-Bertalot, characterized by the rostrate apices that differ from the capitate to subcapitate apices of $P$. biporomum. Planothidium incuriatum is also misidentified as P. rostratum (Østrup) Round \& Bukhtiyarova but it can be distinguished by its smaller dimensions (Wetzel et al. 2013).

Ecology: widely distributed in a broad range of environmental conditions (Wetzel et al. 2013). In our samples, it occurred in circumneutral $\mathrm{pH}$ (6.85), low conductivity $\left(24 \mu \mathrm{S} \mathrm{cm}^{-1}\right)$ and oligotrophic conditions, only in spring (temperature $20.8^{\circ} \mathrm{C}$ ).

Occurrence in samples: natural substrates (UPCB 63375). 
Family DIADESMIDACEAE

Humidophila biscutella (Moser, Lange-Bertalot \& Mezeltin) Lowe, Kociolek, Johansen, Van de Vijver, Lange-Bertalot \& Kopalová

Figure: $3 \mathrm{AK}$

Length: $9.5 \mu \mathrm{m}$; width: $2.3 \mu \mathrm{m}$; indistinct striae.

Valves linear with concave margins and broadly rounded apices; the central area is elliptical and not forming fascia. It is possible that Humidophila biscutella has been previously reported as Humidophila contenta (Grunow) Lowe, Kociolek, Johansen, Van de Vijver, LangeBertalot \& Kopalová. It differs from the latter species by the absence of wide apices and of the central area with fascia (Moser et al. 1998). Humidophila deceptionensis Kopalová, Zidarova \& Van de Vijver is similar to H. biscutella, but has wider valves (2.7-3.2 $\mu \mathrm{m})$ (Kopalová et al. 2015). In Brazil, it was previously registered for reservoirs in São Paulo state (Marquardt et al. 2018).

Ecology: the ecology of this species id little known. In our samples, it occurred only in temperatures $<19^{\circ} \mathrm{C}$, slightly acid to circumneutral $\mathrm{pH}$ (6-6.75), low conductivity (22.5-24.5 $\left.\mu \mathrm{S} \mathrm{cm}^{-1}\right)$ and oligotrophic conditions.

This is the first record for Paraná state.

Occurrence in samples: artificial (UPCB 63373; UPCB 63374) and natural (UPCB 63378) substrates.

Luticola permuticoides Metzeltin \& Lange-Bertalot

Figure: $3 \mathrm{AL}$

Length: 13.5-19.1 $\mu \mathrm{m}$; width: 6.4-7.8 $\mu \mathrm{m}$; striae: 19 in $10 \mu \mathrm{m}$.

Ecology: found in epiphytic samples collected in rivers with slightly acidic waters (Straube et al. 2017). In our samples, it occurred in slightly acid $\mathrm{pH}(6)$, low conductivity $\left(24.5 \mu \mathrm{S} \mathrm{cm}^{-1}\right)$ and oligotrophic conditions, only in winter (temperature $16^{\circ} \mathrm{C}$ ).

Occurrence in samples: natural substrates (UPCB 63378).

Luticola simplex Metzeltin, Lange-Bertalot \& García-Rodríguez Figure: $3 \mathrm{AM}$

Length: $12.8-16 \mu \mathrm{m}$; width: 4.8-5 $\mu \mathrm{m}$; striae: 24 in $10 \mu \mathrm{m}$.

Ecology: previously recorded from sediment samples of subfossil assemblages in oligotrophic conditions and from modern assemblages in eutrophic conditions (Faustino et al. 2016). In our samples, it occurred in circumneutral $\mathrm{pH}(6.75)$, low conductivity $\left(24.5 \mu \mathrm{S} \mathrm{cm}^{-1}\right)$ and oligotrophic conditions, only in summer (temperature of $27^{\circ} \mathrm{C}$ and accumulated rainfall of $326.9 \mathrm{~mm}$ ).

Occurrence in samples: natural substrates (UPCB 63376).

Family AMPHIPLEURACEAE

Frustulia australocrassinervia Casa, Mataloni \& Van de Vijver

Figures: $3 \mathrm{AN}-3 \mathrm{AP}$

Length: 32-43.2 $\mu \mathrm{m}$; width: 8-9.6 $\mu \mathrm{m}$; delicate striae, ratio 3.8-4.6.

This taxon has lanceolate valves, with slightly triundulate margins, protracted and rostrate apices. It differs from Frustulia crassinervia (Brébisson) Lange-Bertalot \& Krammer by the presence of wider valves (11.5-12.5 $\mu \mathrm{m})$ (Casa et al. 2018).

Ecology: previously registered for acidic waters with low conductivity (Casa et al. 2018). It occurred in all samples, in slightly acid to circumneutral $\mathrm{pH}(6-6.85)$, low conductivity $\left(22.5-24.5 \mu \mathrm{S} \mathrm{cm}^{-1}\right)$ and oligotrophic conditions.

This is the first record for Brazil.
Occurrence in samples: artificial (UPCB 63371; UPCB 63372; UPCB 63373; UPCB 63374) and natural (UPCB 63375; UPCB 63376; UPCB 63377; UPCB 63378) substrates.

Frustulia undosa Metzeltin \& Lange-Bertalot

Figures: 3AQ-3AS

Length: $24.5-44.1 \mu \mathrm{m}$; width: 7.5-10 $\mu \mathrm{m}$; delicate striae.

It differs from Frustulia crassinervia (Brébisson) Lange-Bertalot \& Krammer by the presence of a narrower and longer tri-undulated valve (Metzeltin \& Lange-Bertalot 1998).

Ecology: previously registered for a mesotrophic reservoir (Marra et al. 2016). In our samples, it occurred in slightly acid to circumneutral $\mathrm{pH}$ (6-6.75), low conductivity (22.5-24.5 $\left.\mu \mathrm{S} \mathrm{cm}^{-1}\right)$ and oligotrophic conditions.

Occurrence in samples: artificial (UPCB 63373; UPCB 63374) and natural (UPCB 63376; UPCB 63377) substrates.

Family BRACHYSIRACEAE

Brachysira neoexilis Lange-Bertalot

Figures: 3AT-3AV

Length: 16-32 $\mu \mathrm{m}$; width: 4-5.6 $\mu \mathrm{m}$; striae: difficult to distinguish

Wolfe \& Kling (2001) have suggested that Brachysira neoexilis is a synonym of Brachysira microcephala (Grunow) Compère. Some authors consider that both species differ significantly (Cantonati et al. 2017) since the latter species presents clearly capitate apices and usually wider valves than $B$. neoexilis.

Ecology: considered as a species distributed in oligotrophic and acidic conditions (Lange-Bertalot \& Moser 1994, Cantonati et al. 2017), and previously registered for mesotrophic and eutrophic reservoirs (Bertolli et al. 2010, Silva et al. 2010, Marra et al. 2016). It occurred in all our samples, in slightly acid to circumneutral $\mathrm{pH}(6-6.85)$, low conductivity (22.5-24.5 $\left.\mu \mathrm{S} \mathrm{cm}^{-1}\right)$ and oligotrophic conditions.

Occurrence in samples: artificial (UPCB 63371; UPCB 63372; UPCB 63373; UPCB 63374) and natural (UPCB 63375; UPCB 63376; UPCB 63377; UPCB 63378) substrates.

\section{Family NEIDIACEAE}

Neidium affine (Ehrenberg) Pfitzer

Figures: $3 \mathrm{AW}-3 \mathrm{AX}$

Length: 42.9-46.1 $\mu \mathrm{m}$; width: $10-10.8 \mu \mathrm{m}$; striae $25-26$ in $10 \mu \mathrm{m}$.

Ecology: previously registered for oligotrophic and mesotrophic environments (Hofmann 1994, Marra et al. 2016). In our samples, it occurred in circumneutral $\mathrm{pH}(6.7)$, low conductivity $(22.5 \mu \mathrm{S} \mathrm{cm}-1)$ and oligotrophic conditions, only in autumn (temperature of $18.6^{\circ} \mathrm{C}$ ).

Occurrence in samples: natural substrates (UPCB 63377).

Family SELLAPHORACEAE

Sellaphora rectangularis (Gregory) Lange-Bertalot \& Metzeltin Figure: $4 \mathrm{C}$

Length: $31.3-48.8 \mu \mathrm{m}$; width: 7.1-11.7 $\mu \mathrm{m}$; striae: $21-27$ in $10 \mu \mathrm{m}$.

Ecology: previously registered for oligotrophic to eutrophic environments (van Dam et al. 1994, Lange-Bertalot \& Metzeltin 1996). In our samples, it occurred in autumn and winter samples (temperature $<19^{\circ} \mathrm{C}$ ). Thys study extends its occurrence to slightly acid to circumneutral $\mathrm{pH}$ (6-6.7), and low conductivity (22.5-24.5 $\mu \mathrm{S}$ $\mathrm{cm}^{-1}$ ) conditions. 

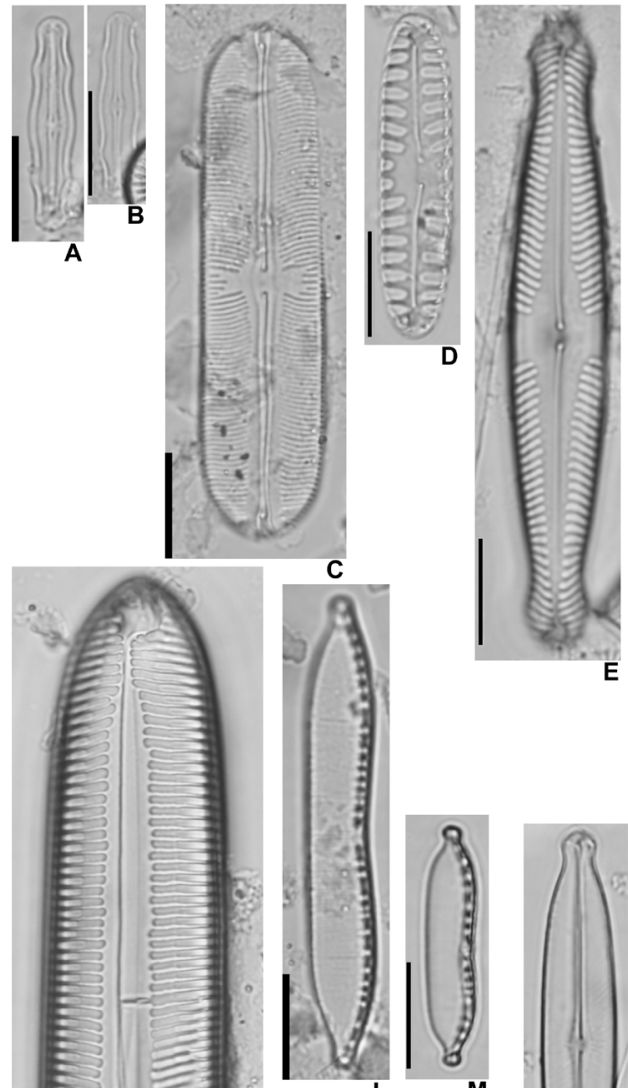

E
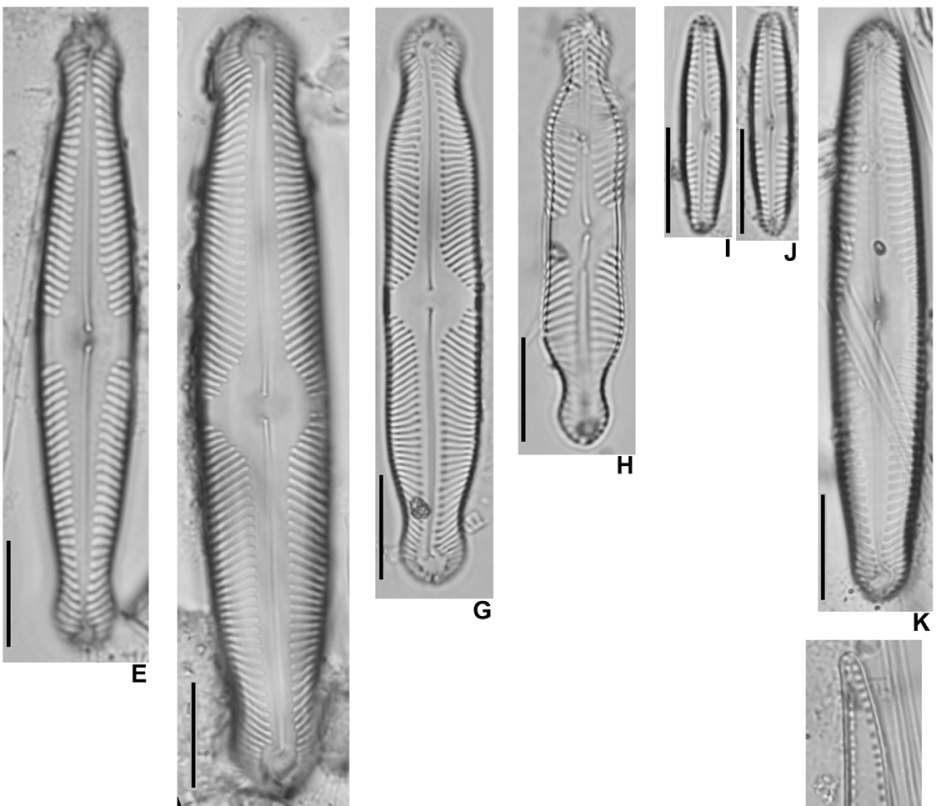

G
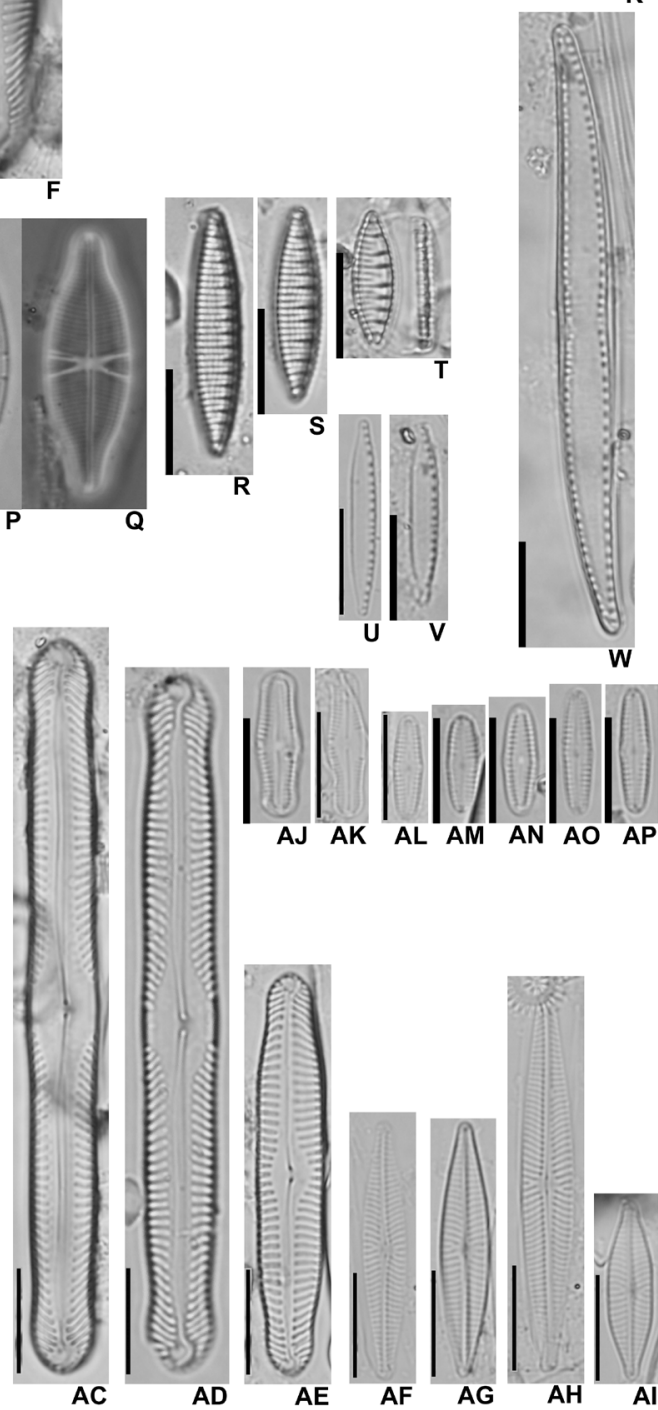

Figure 4. A-B. Sellaphora tridentula; C. Sellaphora rectangularis; D. Pinnularia borealis; E. Pinnularia brauniana; F. Pinnularia divergens var. divergens; G. Pinnularia divergens var. media; H. Pinnularia grunowii; I-J. Pinnularia obscura; K. Pinnularia pseudogibba; L-M. Hantzschia amphioxys; N. Pinnularia schoenfelderi; O. Kobayasiella sp.; P-Q. Capartogramma crucicula; R-T. Nitzschia semirobusta; U-V. Nitzschia acidoclinata; W. Nitzschia nana; X. Pinnularia viridiformis var. viridiformis; Y. Pinnularia viridiformis var. minor; Z. Pinnularia rumrichiae; AA. Pinnularia subcapitata var. elongata; AB. Pinnularia subcapitata var. subrostrata; AC-AD. Pinnularia subgibba var. undulata; AE. Pinnularia submicrostauron; AF. Navicula cryptocephala; AG. Navicula cryptotenella; AH. Navicula leptostriata; AI. Navicula veneta; AJ-AK. Chammaepinularia brasilianopsis; AL-AP. Chammaepinnularia mediocris. 
Occurrence in samples: artificial (UPCB 63373; UPCB 63374) and natural (UPCB 63377) substrates.

\section{Sellaphora tridentula (Krasske) C.E.Wetzel}

Figure: 4A-4B

Length: 17.5-20.8 $\mu \mathrm{m}$; width: 4-4.6 $\mu \mathrm{m}$; striae: difficult to distinguish. Ecology: considered as an acidophile species (van Dam et al. 1994). In our samples, it occurred in spring and autumn (temperature $<21^{\circ} \mathrm{C}$ ). This study extends the occurrence of this species to circumneutral $\mathrm{pH}$ (6.7-6.85), low conductivity (22.5-24 $\left.\mu \mathrm{S} \mathrm{cm}^{-1}\right)$ and oligotrophic conditions.

Occurrence in samples: natural substrates (UPCB 63375; UPCB 63377).

\section{Family PINNULARIACEAE}

Pinnularia borealis Ehrenberg var. borealis.

Figure: 4D

Length: 31-31.2 $\mu \mathrm{m}$; width: 7-7.2 $\mu \mathrm{m}$; striae: 7 in $10 \mu \mathrm{m}$.

Ecology: considered as indifferent to environmental conditions (Hofmann 1994) P. borealis is common in oligo and mesotrophic environments (van Dam et al. 1994, Bertolii et al. 2010), while rarely registered for eutrophic conditions (Silva et al. 2010). In our samples, it occurred in temperature $\mathrm{s}<21^{\circ} \mathrm{C}$, slightly acid to circumneutral $\mathrm{pH}$ (6$6.85)$, low conductivity (24-24.5 $\left.\mu \mathrm{S} \mathrm{cm}^{-1}\right)$ and in oligotrophic conditions. Occurrence in samples: artificial (UPCB 63374) and natural (UPCB 63375) substrates.

Pinnularia brauniana (Grunow) Studnicka.

Figure: 4E

Length: $52.2-60 \mu \mathrm{m}$; width: $8.5-9.6 \mu \mathrm{m}$; striae: $11-12$ in $10 \mu \mathrm{m}$.

Ecology: previously registered for oligotrophic, mesotrophic and eutrophic conditions (Van Dam et al. 1994, Silva et al. 2010, Marra et al. 2016). According to Krammer (1992), P. brauniana is not considered commonly found in waters with low conductivity and $\mathrm{pH}$ $<6$. This study extends its occurrence to temperatures $<21^{\circ} \mathrm{C}$, acid to circumneutral $\mathrm{pH}$ (6-6.85), low conductivity $\left(22.5-24.5 \mu \mathrm{S} \mathrm{cm}^{-1}\right)$, and oligotrophic conditions.

Occurrence in samples: artificial (UPCB 63371; UPCB 63373; UPCB 63374) and natural (UPCB 63375; UPCB 63377; UPCB 63378) substrates.

Pinnularia divergens Smith var. divergens

Figure: $4 \mathrm{~F}$

Length: $74.5 \mu \mathrm{m}$; width: $12.5 \mu \mathrm{m}$; striae: 12 in $10 \mu \mathrm{m}$.

Ecology: in agreement with previously studies (van Dam et al. 1994, Cantonati et al. 2017), we found this species in $\mathrm{pH}<7$, low conductivity $\left(22.5 \mu \mathrm{S} \mathrm{cm}^{-1}\right)$ and oligotrophic conditions only in autumn (temperature $\left.18.6^{\circ} \mathrm{C}\right)$.

Occurrence in samples: natural substrates (UPCB 63377).

Pinnularia divergens var. media Krammer

Figure: $4 \mathrm{G}$

Length: 39-54.5 $\mu \mathrm{m}$; width: 7.7-9.5 $\mu \mathrm{m}$; striae: $14-15$ in $10 \mu \mathrm{m}$.

Ecology: according to previous studies, this species prefers oligotrophic environments (van Dam et al. 1994, Cantonati et al. 2017) but can also occur in eutrophic waters (Silva et al. 2010). In our samples, it occurred in in temperatures $<21^{\circ} \mathrm{C}$, slightly acid to circumneutral $\mathrm{pH}(6-6.85)$, low conductivity (24-24.5 $\left.\mu \mathrm{S} \mathrm{cm}^{-1}\right)$ and in oligotrophic conditions.

Occurrence in samples: natural substrates (UPCB 63375; UPCB 63377; UPCB 63378).

\section{Pinnularia grunowii Krammer}

Figure: $4 \mathrm{H}$

Length: $31-41 \mu \mathrm{m}$; width: $6-7.5 \mu \mathrm{m}$; striae: 14 in $10 \mu \mathrm{m}$.

Ecology: previously registered for eutrophic environments, with low to moderate electrolytes and $\mathrm{pH}>8$ (Krammer 2000) and also for mesotrophic waters (Bertolli et al. 2010). In our samples, it occurred in circumneutral $\mathrm{pH}(6.7-6.85)$ and low conductivity $\left(22.5-24.5 \mu \mathrm{S} \mathrm{cm}^{-1}\right)$, and oligotrophic conditions.

Occurrence in samples: artificial (UPCB 63373) and natural (UPCB 63375; UPCB 63376) substrates.

\section{Pinnularia obscura Krasske}

Figures: 4I-4J

Length: $20.5-21.5 \mu \mathrm{m}$; width: 4-4.5 $\mu \mathrm{m}$; striae: 16 in $10 \mu \mathrm{m}$.

Ecology: considered as a species tolerant to environments with $\mathrm{pH}<$ 4 (Ciniglia et al. 2007). In our samples, it occurred in circumneutral pH (6.7-6.85), low conductivity (22.5-24 $\left.\mu \mathrm{S} \mathrm{cm}^{-1}\right)$, and oligotrophic conditions, in spring and autumn (temperature $<21^{\circ} \mathrm{C}$ ).

Occurrence in samples: natural substrates (UPCB 63375; UPCB 63377).

Pinnularia pseudogibba Krammer

Figure: $4 \mathrm{~K}$

Length: $54 \mu \mathrm{m}$; width: $9 \mu \mathrm{m}$; striae: 11 in $10 \mu \mathrm{m}$.

Pinnularia pseudogibba differs from Pinnularia subgibba Krammer var. subgibba by the presence of lanceolate valves with subrostrate apices (Krammer 2000).

Ecology: previously registered for oligotrophic environments (Krammer 2000). In our samples, it occurred in slightly acid to circumneutral $\mathrm{pH}$ (6$6.85)$, low conductivity (24-24.5 $\left.\mu \mathrm{S} \mathrm{cm}^{-1}\right)$ and oligotrophic conditions. Occurrence in samples: artificial (UPCB 63371; UPCB 63374) and natural (UPCB 63375; UPCB 63376; UPCB 63377) substrates.

\section{Pinnularia rumrichae Krammer.}

Figure: $4 \mathrm{Z}$

Length: $45-46.5 \mu \mathrm{m}$; width: $7.5-8 \mu \mathrm{m}$; striae: 13 in $10 \mu \mathrm{m}$.

Ecology: in our samples, it occurred in slightly acidic to circumneutral $\mathrm{pH}$ (6-6.85), low conductivity (24-24.5 $\left.\mu \mathrm{S} \mathrm{cm}^{-1}\right)$ and in oligotrophic conditions.

Occurrence in samples: artificial (UPCB 63373) and natural (UPCB 63375; UPCB 63376; UPCB 63378) substrates.

\section{Pinnularia schoenfelderi Krammer.}

Figure: $4 \mathrm{~N}$

Length: $23 \mu \mathrm{m}$; width: $4.8 \mu \mathrm{m}$; striae: 16 in $10 \mu \mathrm{m}$.

Ecology: previously registered for oligotrophic environments with low to moderate conductivity (Krammer 2000), and also for mesotrophic waters (Bertollit et al. 2010). In our samples, it occurred in circumneutral $\mathrm{pH}$ (6.7), low conductivity $\left(22.5 \mu \mathrm{S} \mathrm{cm}^{-1}\right)$ and oligotrophic conditions, only in autumn (temperature $18.6^{\circ} \mathrm{C}$ ).

Occurrence in samples: natural substrates (UPCB 63377). 
Pinnularia subcapitata var. elongata Krammer.

Figure: 4AA

Length: $43.5 \mu \mathrm{m}$; width: $6 \mu \mathrm{m}$; striae: 16 in $10 \mu \mathrm{m}$.

Ecology: commonly associated with sphagnum moss (Krammer 1992). In our samples, it occurred in slightly acid $\mathrm{pH}(6)$, low conductivity (24.5 $\mu \mathrm{S} \mathrm{cm}^{-1}$ ) and oligotrophic conditions, only in winter (temperature $16^{\circ} \mathrm{C}$ ). Occurrence in samples: artificial substrates (UPCB 63374).

\section{Pinnularia subcapitata var. subrostrata Krammer}

Figure: $4 \mathrm{AB}$

Length: 38.5-46.5 $\mu \mathrm{m}$; width: 6-6.5 $\mu \mathrm{m}$; striae: 13 in $10 \mu \mathrm{m}$.

Ecology: widespread species; common in waters with medium electrolyte concentrations (Krammer 1992). In our samples, it occurred in circumneutral $\mathrm{pH}(6.7-6.85)$, low conductivity $\left(22.5-24.5 \mu \mathrm{S} \mathrm{cm} \mathrm{cm}^{-1}\right)$ and oligotrophic conditions.

Occurrence in samples: artificial (UPCB 63373) and natural (UPCB 63375; UPCB 63376; UPCB 63377) substrates.

\section{Pinnularia subgibba var. undulata Krammer}

Figures: 4AC-4AD

Length: $65.1-68.5 \mu \mathrm{m}$; width: 7-7.8 $\mu \mathrm{m}$; striae: $11-12$ in $10 \mu \mathrm{m}$.

Ecology: previously registered for waters with neutral $\mathrm{pH}$ and high conductivity (Noga et al. 2014). In Brazil, it was recorded from planktonic samples in Guaraguaçu River (Tremarin et al. 2010) and from epiphytic samples in a mesotrophic reservoir of the South region (Marra et al. 2016). This study expanded its occurrence to circumneutral $\mathrm{pH}$ (6.7-6.85), low conductivity (22.5-24.5 $\left.\mu \mathrm{S} \mathrm{cm}^{-1}\right)$ and oligotrophic conditions.

Occurrence in samples: artificial (UPCB 63373) and natural (UPCB 63375; UPCB 63376; UPCB 63377) substrates.

\section{Pinnularia submicrostauron Schroeter}

Figure: 4AE

Length: $38.4-43.7 \mu \mathrm{m}$; width: 5-6.6 $\mu \mathrm{m}$; striae: $12-13$ in $10 \mu \mathrm{m}$.

Ecology: previously registered as epiphytic in non-polluted environments, with acid $\mathrm{pH}(3.95-5.89)$ and medium to high conductivity (46-94 $\mu \mathrm{S} \mathrm{cm}^{-1}$ ) (Krammer 1992, Veselá 2009, Szulc et al. 2014). In our samples, it occurred in circumneutral $\mathrm{pH}$ (6.7), low conductivity (22.5-24.5 $\left.\mu \mathrm{S} \mathrm{cm}^{-1}\right)$ and oligotrophic conditions.

Occurrence in samples: artificial (UPCB 63373) and natural (UPCB 63376; UPCB 63377) substrates.

\section{Pinnularia viridiformis var. viridiformis Krammer}

Figure: $4 \mathrm{X}$

Length: $131 \mu \mathrm{m}$; width: $17.3 \mu \mathrm{m}$; striae: 10 in $10 \mu \mathrm{m}$.

Ecology: this species is frequently sampled especially in oligotrophic and mesotrophic environments, with low to moderate conductivity (Krammer 2000, Bertolli et al. 2010), being more abundant in acid pH (Van de Vijver \& Beyen 1997, Veselá 2014). In our study, it was only recorded from samples of periphyton associated with aquatic macrophytes (75\%), in slightly acid to circumneutral $\mathrm{pH}$ (6-6.85), low conductivity (24-24.5 $\left.\mu \mathrm{S} \mathrm{cm}^{-1}\right)$ and oligotrophic conditions.

Occurrence in samples: natural substrates (UPCB 63375; UPCB 63376; UPCB 63378).
Pinnularia viridiformis var. minor Krammer.

Figure: $4 \mathrm{Y}$

Length: 52-82.5 $\mu \mathrm{m}$; width: 11-12.5 $\mu \mathrm{m}$; striae: $10-12$ in $10 \mu \mathrm{m}$.

Pinnularia viridiformis var. minor differs from Pinnularia viridis (Nitzsch) Ehrenberg by the valve outline and by the presence of a semi complex raphe (Krammer 2000).

Ecology: considered as cosmopolitan (Krammer 2000); it is rare in waters with neutral to alkaline $\mathrm{pH}$ and in moderate to high conductivity (Cremer et al. 2004, Noga et al. 2014). It was previously registered for streams with acid $\mathrm{pH}$ and low conductivity, in Central Brazil (França et al. 2017). In our study, it was recorded from samples of periphyton associated with aquatic macrophytes, in temperatures of $16^{\circ} \mathrm{C}$, acid $\mathrm{pH}$ (6), low conductivity $\left(24.5 \mu \mathrm{S} \mathrm{cm}^{-1}\right)$, and oligotrophic conditions. This is the first record for Paraná state.

Occurrence in samples: natural substrates (UPCB 63378).

\section{Order NAVICULALES}

Family incertae sedis

Chamaepinnularia brasilianopsis Metzeltin \& Lange-Bertalot

Figures: 4AJ-4AK

Length: 13.5-13.9 $\mu \mathrm{m}$; width: 3.5-4.1 $\mu \mathrm{m}$; striae: 24 in $10 \mu \mathrm{m}$.

Ecology: previously described for the Neotropical region (Metzeltin \& Lange-Bertalot 1998), in mesotrophic waters (Marra et al. 2016). with circumneutral to slightly alkaline $\mathrm{pH}$, and conductivity between 24.3 and $145 \mu \mathrm{S} \mathrm{cm}^{-1}$ (Sala et al. 2015). In our study, it was only registered in autumn, from samples of macrophytes, in temperatures of $18.6^{\circ} \mathrm{C}$, circumneutral $\mathrm{pH}(6.7)$, low conductivity $\left(22.5 \mu \mathrm{S} \mathrm{cm}^{-1}\right)$ and oligotrophic conditions.

Occurrence in samples: natural substrates (UPCB 63377).

Chamaepinnularia mediocris (Krasske) Lange-Bertalot \& Krammer Figures: 4AL-4AP

Length: $10-14.7 \mu \mathrm{m}$; width: $2.5-3 \mu \mathrm{m}$; striae: $21-24$ in $10 \mu \mathrm{m}$.

Ecology: considered as characteristic of oligotrophic environments (van Dam et al. 1994, Hofmann 1994), but also cited for mesotrophic and eutrophic waters (Silva et al. 2010, Marra et al. 2016). It is a good indicator of environments rich in minerals, with moderate to high conductivity, and acid pH (Fránková et al. 2009), and also associated with the process of deglaciation (Fell et al. 2018). In our study, it occurred in summer (temperature of $27^{\circ} \mathrm{C}$ and high acummulated rainfall), in waters with slightly acid to circumneutral $\mathrm{pH}$ (6-6.75), low conductivity (22.5-24.5 $\left.\mu \mathrm{S} \mathrm{cm}^{-1}\right)$, and oligotrophic conditions.

Occurrence in samples: artificial (UPCB 63372) and natural (UPCB 63377; UPCB 63378) substrates.

\section{Kobayasiella sp.}

Figure: 40

Length: $39.8 \mu \mathrm{m}$; width: $7.4 \mu \mathrm{m}$; striae: 15 in $10 \mu \mathrm{m}$.

Kobayasiella sp. presents linear-elliptic valves with subcapitate ends. The axial area is linear and straight. The central area is elliptic and delimited by irregular striae that are radiate towards the valve center. The valve outline is similar to Kobayasiella acidophila Vanhoutte, Kobayasiella subtilissima (Cleve) Lange-Bertalot and Kobayasiella tapajoensis Metzeltin \& Lange-Bertalot, but these three latter taxa 
present smaller size $(24.7-31.2 \mu \mathrm{m}, 23-27 \mu \mathrm{m}$, and 23-34 $\mu \mathrm{m}$, respectively) and a higher striae density (34-42, 36-40 and 34-38 in $10 \mu \mathrm{m}$, respectively). Kobayasiella sp. is also similar to Kobayasiella floridana Metzeltin \& Lange-Bertalot and Kobayasiella krasskei (Metzeltin \& Lange-Bertalot) Lange-Bertalot, but these species have larger valves (54-83 $\mu \mathrm{m}$ and 44-50 $\mu \mathrm{m}$, respectively) and higher striae density (28-32 and 27-28 in $10 \mu \mathrm{m}$, respectively) (Metzeltin \& LangeBertalot 2007, 1998, Vanhoutte et al. 2004).

Occurrence in samples: natural substrates (UPCB 63377).

\section{Family NAVICULACEAE}

\section{Navicula cryptocephala Kützing}

Figure: $4 \mathrm{AF}$

Length: $23.2-39.2 \mu \mathrm{m}$; width: 4.8-6 $\mu \mathrm{m}$; striae: $12-18$ in $10 \mu \mathrm{m}$.

Ecology: cosmopolitan; registered for oligotrophic to eutrophic environments, but more abundant in mesotrophic waters (Bertolli et al. 2010, Bartozek et al. 2018). In our study, it occurred in slightly acid to circumneutral $\mathrm{pH}$ (6-6.85), low conductivity $\left(22.5-24.5 \mu \mathrm{S} \mathrm{cm}^{-1}\right)$, and oligotrophic conditions.

Occurrence in samples: artificial (UPCB 63371; UPCB 63372; UPCB 63373) and natural (UPCB 63375; UPCB 63376; UPCB 63378) substrates.

Navicula cryptotenella Lange-Bertalot.

Figure: $4 \mathrm{AG}$

Length: $20-35 \mu \mathrm{m}$; width: $4.5-5.6 \mu \mathrm{m}$; striae: $12-18$ in $10 \mu \mathrm{m}$.

Ecology: widely distributed in oligotrophic to eutrophic conditions (Bertolii et al. 2010, Silva et al. 2010, Marra et al. 2016, Bartozek et al. 2018, Santos \& Ferragut 2018), but most commonly associated with low TP concentrations (Wang et al. 2019). It occurred in all of our samples, in slightly acid to circumneutral $\mathrm{pH}$ (6-6.85), low conductivity (22.5-24.5 $\left.\mu \mathrm{S} \mathrm{cm}^{-1}\right)$, and oligotrophic conditions.

Occurrence in samples: artificial (UPCB 63371; UPCB 63372; UPCB 63373; UPCB 63374) and natural (UPCB 63375; UPCB 63376; UPCB 63377; UPCB 63378) substrates.

\section{Navicula leptostriata Jørgensen}

Figure: $4 \mathrm{AH}$

Length: $33-36.3 \mu \mathrm{m}$; width: $4.5-4.8 \mu \mathrm{m}$; striae: $17-18$ in $10 \mu \mathrm{m}$.

Ecology: previously registered for environments with moderate to high nutrient concentrations (van Dam et al. 1994, Silva et al. 2010, Ma et al. 2014). In our study, it occurred in temperatures $<21^{\circ} \mathrm{C}$, slightly acid and circumneutral $\mathrm{pH}$ (6-6.85), low conductivity $\left(22.5-24.5 \mu \mathrm{S} \mathrm{cm}^{-1}\right)$, and oligotrophic conditions.

Occurrence in samples: artificial (UPCB 63374) and natural (UPCB 63375; UPCB 63377) substrates.

\section{Navicula veneta Kützing}

Figure: 4AI

Length: $17 \mu \mathrm{m}$; width: $4 \mu \mathrm{m}$; striae: 18 in $10 \mu \mathrm{m}$.

Ecology: commonly registered for environments rich in nutrients (van Dam et al. 1994, Hofmann 1994, Silva et al. 2010, Marra et al. 2016, Casco et al. 2018). In our samples, it only occurred in autumn (temperature of $\left.18.6^{\circ} \mathrm{C}\right)$. This study expanded its occurrence to circumneutral $\mathrm{pH}(6.7)$, low conductivity $\left(22.5 \mu \mathrm{S} \mathrm{cm}^{-1}\right)$ and oligotrophic conditions.

Occurrence in samples: natural substrates (UPCB 63377).
Capartogramma crucicula (Grunow ex Cleve) Ross

Figures: $4 \mathrm{P}-4 \mathrm{Q}$

Length: $27.5 \mu \mathrm{m}$; width: $8.5 \mu \mathrm{m}$; striae: 21 in $10 \mu \mathrm{m}$.

Ecology: the ecological optimum of this species is difficult to define (Beyene et al. 2014). It was previously registered for the oligotrophic paleophase (Faustino et al. 2016) and for modern mesotrophic conditions (Marra et al. 2016). In our study, it occurred in circumneutral pH (6.85), low conductivity $\left(24 \mu \mathrm{S} \mathrm{cm}^{-1}\right)$ and oligotrophic conditions, only in spring (temperature of $20.8^{\circ} \mathrm{C}$ ).

Occurrence in samples: artificial substrates (UPCB 63771).

\section{Family STAURONEIDACEAE}

Stauroneis neohyalina Lange-Bertalot \& Krammer

Figures: $5 \mathrm{~A}-5 \mathrm{~B}$

Length: $43-52 \mu \mathrm{m}$; width: $8-8.7 \mu \mathrm{m}$; striae: difficult to distinguish under the LM.

Stauroneis neohyalina differs from Stauroneis gracilior (Rabenhorst) Reichardt by the presence of subcapitate apices, narrower valves and a higher striae density. The striae are difficult to distinguish under the light microscope and the areolae are inconspicuous (Reichardt 1995, Lange-Bertalot \& Metzeltin 1996). In this species, the proximal ends of the raphe are straight and not inflated and teardrop-shaped as in $S$. gracilior (Cantonati et al. 2017).

Widely recorded in different worldwide regions (Guiry \& Guiry 2018). This is the first record for Brazil.

Ecology: previously registered for oligotrophic and acidic environments (van Dam et al. 1994, Sienkiewicz 2005, Van de Vijver et al. 2005, Krstić et al. 2012). In our samples, it occurred in slightly acid to circumneutral $\mathrm{pH}$ (6-6.75), low conductivity (22.5-24.5 $\left.\mu \mathrm{S} \mathrm{cm}^{-1}\right)$ and oligotrophic conditions, in summer (temperature of $27^{\circ} \mathrm{C}$ ).

Occurrence in samples: artificial (UPCB 63373) and natural (UPCB 63376; UPCB 63378) substrates.

\section{Stauroneis gracilis Ehrenberg}

Figure: $5 \mathrm{C}$

Length: $83.5 \mu \mathrm{m}$; width: $13.5 \mu \mathrm{m}$; striae: 23 in $10 \mu \mathrm{m}$.

Ecology: considered as characteristic of oligotrophic environments (Dixit \& Smol 1995); it is rare in mesotrophic and eutrophic conditions (Silva et al. 2010, Marra et al. 2016) and has its optimum in conditions of low conductivity (Pestryakova et al. 2018). In our study, it only occurred from samples of aquatic macrophytes, in circumneutral $\mathrm{pH}$ (6.7), low conductivity $\left(22.5 \mu \mathrm{S} \mathrm{cm}^{-1}\right)$ and oligotrophic conditions, in autumn (temperature of $18.6^{\circ} \mathrm{C}$ ).

Occurrence in samples: natural substrates (UPCB 63377).

\section{Stauroneis phoenicenteron (Nitzsch) Ehrenberg}

Figure: 5D

Length: $96.5-116.5 \mu \mathrm{m}$; width: 18.2-22.5 $\mu \mathrm{m}$; striae: $18-19$ in $10 \mu \mathrm{m}$.

Ecology: considered as characteristic of meso-eutrophic environments (van Dam et al. 1994, Silva et al. 2010, Bertolii et al. 2010), it has its optimum in conditions of intermediate conductivity (Pestryakova et al. 2018) and acid to circumneutral pH (Ma et al. 2014). In this samples, it occurred in slightly to circumneutral $\mathrm{pH}$ (6-6.7), low conductivity (22.5$24.5 \mu \mathrm{S} \mathrm{cm}^{-1}$ ) and oligotrophic conditions, in autumn (temperature $<21^{\circ} \mathrm{C}$ ). Occurrence in samples: artificial (UPCB 63373; UPCB 63374) and natural (UPCB 63377) substrates. 

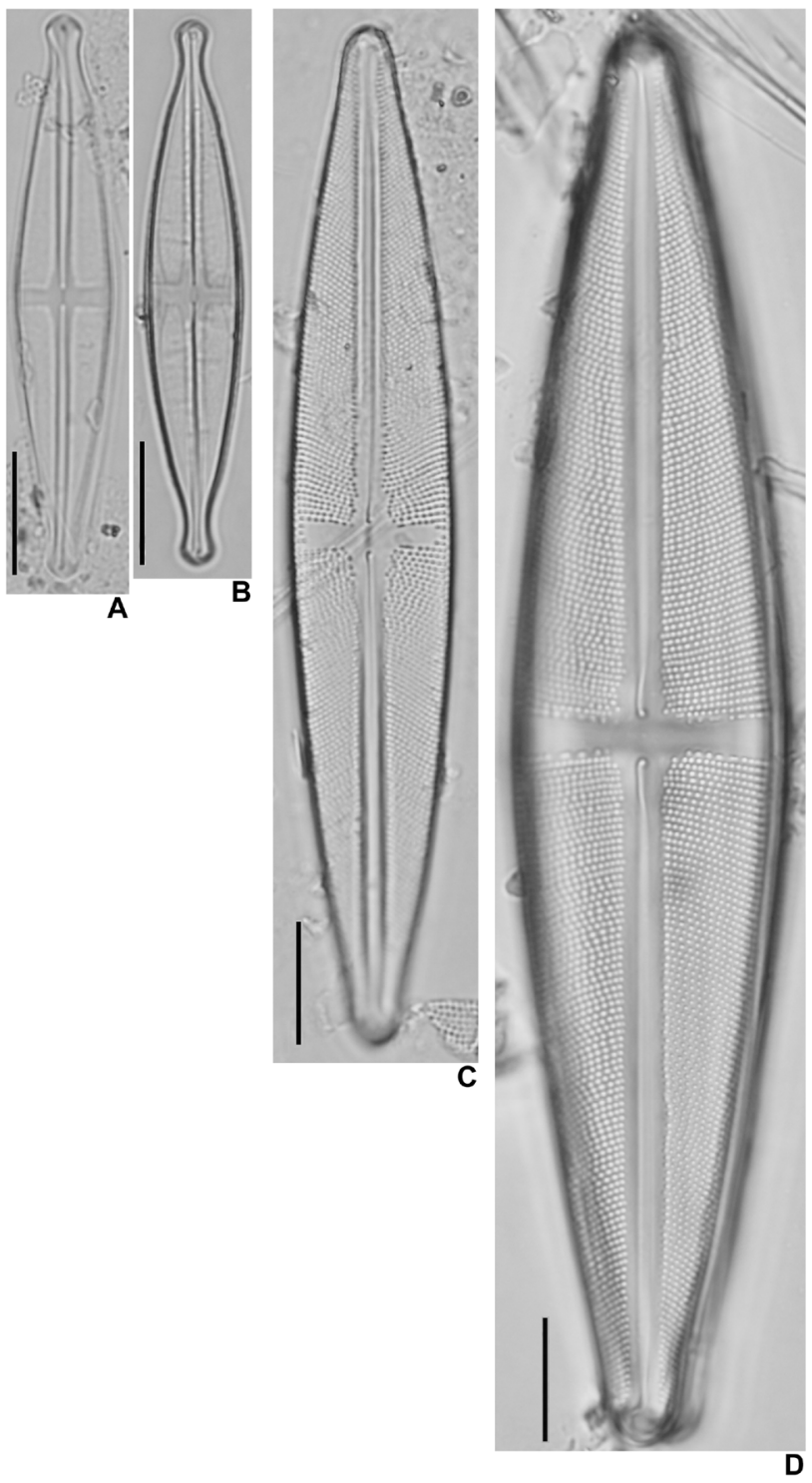
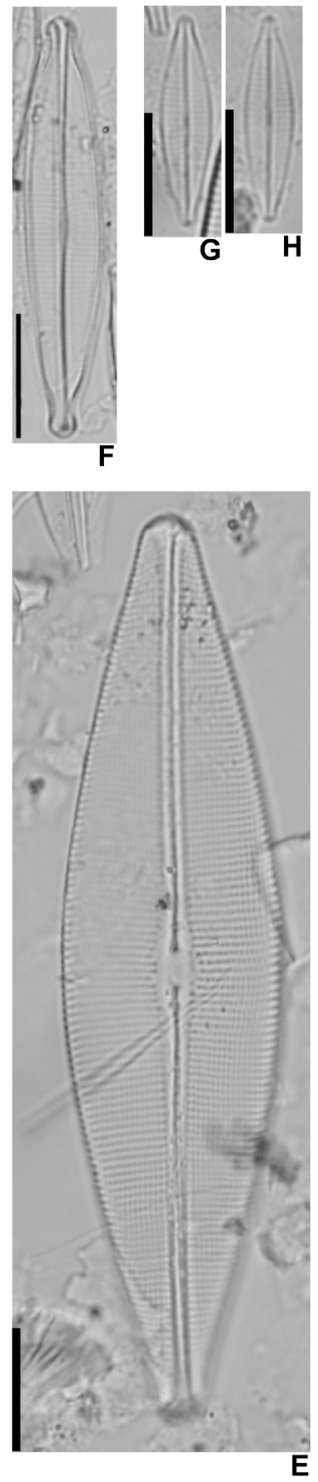
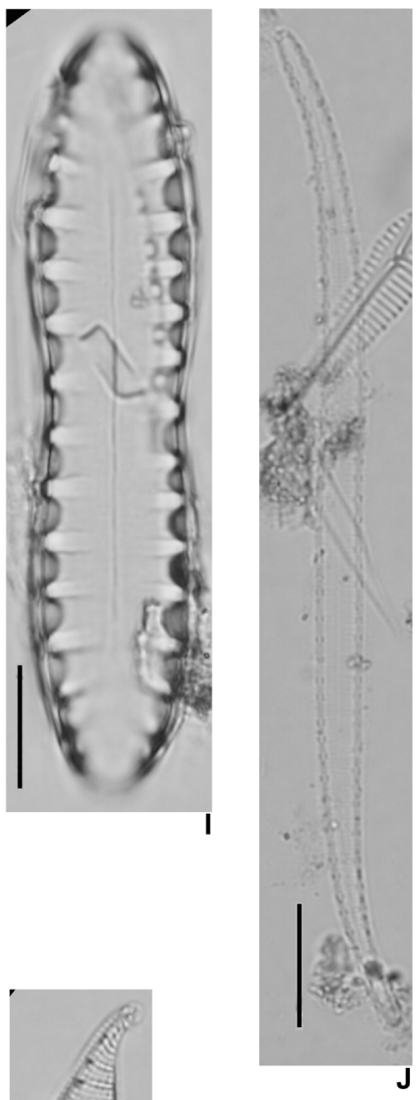

Figure 5. A-B. Stauroneis neohyalina; C. Stauroneis gracilis; D. Stauroneis phoenicenteron; E. Craticula acidoclinata; F. Craticula riparia var. mollenhaurei; G-H. Craticula submolesta; I. Surirella grunowii; J. Iconella curvula; K. Rhopalodia gibberula var. vanheurckii.

\section{Craticula acidoclinata Lange-Bertalot \& Metzeltin}

Figure: $5 \mathrm{E}$

Length: $65-1-74.2 \mu \mathrm{m}$; width: 17.9-18.5 $\mu \mathrm{m}$; striae: 15 in $10 \mu \mathrm{m}$; areolae: 24 in $10 \mu \mathrm{m}$.

Craticula acidoclinata differs from Craticula ambigua (Ehrenberg) Mann by the presence of subrostrate apices and broadly rounded ends in the valves (distinctly protracted and rostrate in C. ambigua). Craticula cuspidata (Kützing) Mann has wider valves with narrower apices (Lange-Bertalot \& Metzeltin 1996).

Ecology: registered for acid environments, poor in nutrients (Cantonati et al. 2017). It was previously found in Rio Tapajós, Brazil (Metzeltin \& Lange-Bertalot 1998). In our samples, it occurred in circumneutral $\mathrm{pH}(6.7)$, low conductivity $\left(22.5 \mu \mathrm{S} \mathrm{cm}^{-1}\right)$ and oligotrophic conditions, in autumn (temperature $<21^{\circ} \mathrm{C}$ ).

This is the first record for Paraná state.
Occurrence in samples: natural substrates (UPCB 63377).

Craticula riparia var. mollenhaurei Lange-Bertalot.

Figure: $5 \mathrm{~F}$

Length: $33.5 \mu \mathrm{m}$; width: $7 \mu \mathrm{m}$; striae: 24 in $10 \mu \mathrm{m}$.

Craticula riparia var. mollenhaurei resembles Craticula riparia (Hustedt) Lange-Bertalot var. riparia Lange-Bertalot in the valve outline but differs from the latter by the presence of longer and wider valves (35-50 $\mu \mathrm{m}$ and 8-10.5 $\mu \mathrm{m})$ and a lower striae density (15-18 in $10 \mu \mathrm{m})$. Craticula riparia var. riparia is common in eutrophic environments with high conductivity (Lange-Bertalot 2001, van Dam et al. 1994).

Ecology: previously registered for slightly acid to neutral waters, with low conductivity (Lange-Bertalot 2001, Lange-Bertalot 1993). In our samples, it occurred in circumneutral $\mathrm{pH}$ (6.7), low conductivity $(22.5$ $\mu \mathrm{S} \mathrm{cm}^{-1}$ ) and oligotrophic conditions, in.autumn (temperature $<21^{\circ} \mathrm{C}$ ). 
This is the first record for Brazil.

Occurrence in samples: natural substrates (UPCB 63377).

Craticula submolesta (Hustedt) Lange-Bertalot

Figures: $5 \mathrm{G}-5 \mathrm{H}$

Length: $16.8-17.1 \mu \mathrm{m}$; width: 4-4.3 $\mu \mathrm{m}$; striae: $22-24$ in $10 \mu \mathrm{m}$.

Ecology: considered as characteristic of oligotrophic environments (Lange-Bertalot \& Metzeltin 1996), it is rarely found in mesotrophic conditions (Marra et al. 2016). In our samples, it occurred in circumneutral $\mathrm{pH}(6.7)$, low conductivity $\left(22.5 \mu \mathrm{S} \mathrm{cm}^{-1}\right)$ and oligotrophic conditions, in autumn (temperature $<21^{\circ} \mathrm{C}$ ).

Occurrence in samples: natural substrates (UPCB 63377).

Family BACILLARIACEAE

Nitzschia acidoclinata Lange-Bertalot

Figure: $4 \mathrm{U}-4 \mathrm{~V}$

Length: 21-38.7 $\mu \mathrm{m}$; width: 2.5-3 $\mu \mathrm{m}$; indistinct striae; fibulae: $13-14$ in $10 \mu \mathrm{m}$.

Ecology: previously registered for oligo-mesotrophic environments (van Dam et al. 1994, Hofmann 1994). In our samples, it occurred in temperatures $<21^{\circ} \mathrm{C}$, slightly acid to circumneutral $\mathrm{pH}$ (6-6.85), low conductivity $\left(22.5-24.5 \mu \mathrm{S} \mathrm{cm}^{-1}\right)$ and oligotrophic conditions.

Occurrence in samples: artificial (UPCB 63373; UPCB 63374) and natural (UPCB 63375; UPCB 63378) substrates.

\section{Nitzschia nana Grunow}

Figure: $4 \mathrm{~W}$

Length: 58.3, width: $5.2 \mu \mathrm{m}$; indistinct striae; fibulae: 10 in $10 \mu \mathrm{m}$.

Ecology: it avoids saprobic environments (Cantonati et al. 2017). In our samples, it occurred in circumneutral $\mathrm{pH}$ (6.85), low conductivity (24 $\mu \mathrm{S} \mathrm{cm}-1$ ) and oligotrophic conditions, in spring (temperature $<21^{\circ} \mathrm{C}$ ).

Occurrence in samples: natural substrates (UPCB 63375)

Nitzschia semirobusta Lange-Bertalot.

Figures: 4R-4T

Length: $16-20 \mu \mathrm{m}$; width: $4.5-5 \mu \mathrm{m}$; striae: $16-18$ in $10 \mu \mathrm{m}$; fibulae: 7 in $10 \mu \mathrm{m}$.

Nitzschia semirobusta differs from Nitzschia amphibia Grunow by the presence of longer fibulae and from Nitzschia amphibioides Hustedt by having a greater striae density. Denticula kuetzingii Grunow is distinguished from Nitzschia semirobusta by the presence of fibulae that are extended completely and with similar thickness from margin to margin in the first species (Lange-Bertalot 1993), while in the latter species the fibulae decrease in thickness towards the margin.

Ecology: Due to the taxonomic problems and misidentification, the ecological preference of $N$. semirobusta is unclear. Therefore, information on its occurrence and ecological preferences is of high relevance for delimiting the ecological requirements and tolerances of $N$. semirobusta. It was frequently registered for oligo- to mesotrophic reservoirs in São Paulo state (Bartozek et al. 2018). In our samples, it occurred in slightly acid to circumneutral $\mathrm{pH}$ (6-6.85), low conductivity (22.5-24.5 $\left.\mu \mathrm{S} \mathrm{cm}^{-1}\right)$ and oligotrophic conditions.

This is the first record for Paraná state.

Occurrence in samples: artificial (UPCB 63371; UPCB 63374) and natural (UPCB 63375; UPCB 63376; UPCB 63377; UPCB 63378) substrates.
Hantzschia amphioxys (Ehrenberg) Grunow

Figure: 4L-4M

Length: 23.5-45 $\mu \mathrm{m}$; width: 5-5.6 $\mu \mathrm{m}$; indistinct striae; fibulae: 8-9 in $10 \mu \mathrm{m}$.

Ecology: common in soil and aerial habitats (Jahn et al. 2014), and considered as tipically indifferent to trophic conditions (van Dam et al. 1994, Hofmann 1994). It is rarely found in waters poor in nutrients, being more common in mesotrophic environments (Bertolli et al. 2010, Bartozek et al. 2018, Cuña-Rodríguez et al. 2018) and eutrophic conditions (Silva et al. 2010). Previous studies associated this species with cold waters (Darling et al. 2017), however, in our samples it only occurred in summer (temperature $27^{\circ} \mathrm{C}$ ), in circumneutral $\mathrm{pH}(6.75)$, low conductivity $\left(24.5 \mu \mathrm{S} \mathrm{cm}^{-1}\right)$ and oligotrophic conditions.

Occurrence in samples: natural substrates (UPCB 63376).

\section{Family RHOPALODIACEAE}

Rhopalodia gibberula var. vanheurckii O. Müller

Figure: $5 \mathrm{~K}$

Length: $35.1-36.3 \mu \mathrm{m}$; width: $8-8.5 \mu \mathrm{m}$; striae: $14-19$ in $10 \mu \mathrm{m}$; transapical ribs: $4-5$ in $10 \mu \mathrm{m}$.

Ecology: considered as an alkalinophilous species (van Dam et al. 1994). In our samples, it occurred in slightly acid pH (6), low conductivity $\left(24.5 \mu \mathrm{S} \mathrm{cm}^{-1}\right)$ and oligotrophic conditions, only in winter (temperature $16^{\circ} \mathrm{C}$ ),

Occurrence in samples: natural substrates (UPCB 63378).

Family SURIRELLACEAE

Surirella grunowii Kulikovskiy, Lange-Bertalot \& Witkovski.

Figure: 5I

Length: $62.4-76.1 \mu \mathrm{m}$; width: 11.5-11.6 $\mu \mathrm{m}$; striae: difficult to distinguish; alar canals: $3-4$ in $10 \mu \mathrm{m}$.

Surirella linearis var. constricta Grunow was synonymized with $S$. grunowii by Kulikovskiy et al. (2010).

Ecology: previously registered for oligo-mesotrophic environments (van Dam et al. 1994). In our samples, it occurred in circumneutral $\mathrm{pH}$ (6.7-6.85), low conductivity (22.5-24 $\left.\mu \mathrm{S} \mathrm{cm}^{-1}\right)$ and oligotrophic conditions, in spring and autumn seasons (temperature $<21{ }^{\circ} \mathrm{C}$ ).

Occurrence in samples: artificial (UPCB 63371) and natural (UPCB 63377) substrates.

\section{Iconella curvula (Smith) Ruck \& Nakov}

Figure: $5 \mathrm{~J}$

Length: $92 \mu \mathrm{m}$; width: $4 \mu \mathrm{m}$; indistinct striae; alar canals: 7 in $10 \mu \mathrm{m}$. Ecology: cited as Stenopterobia curvula (Smith) Krammer, it was registered for oligotrophic (van Dam et al. 1994) and mesotrophic environments (Marra et al. 2016). In our samples, it occurred in circumneutral $\mathrm{pH}(6.75)$, low conductivity $(24.5 \mu \mathrm{S} \mathrm{cm}-1)$ and oligotrophic conditions, only in summer (temperature $27^{\circ} \mathrm{C}$ ).

Occurrence in samples: natural substrates (UPCB 63376).

\section{Conclusions}

The inventory performed at the Piraquara I reservoir brings an important contribution to the diatom diversity from oligotrophic environments. We registered the first occurrence of five diatom species in Brazil and seven in the state of Paraná, contributing to the geographic 
distribution and the ecology of the identified species. Finally, fourteen periphytic species extended their ecological limits of $\mathrm{pH}$, conductivity and trophic preferences.

\section{Acknowledgments}

To "Conselho Nacional de Desenvolvimento Científico e Tecnológico" (CNPq) for the master's scholarship (AMSL), scientific productivity scholarship (TAVL) and financial support for the project (CTHidro-555397/2006-8). To IAP and SANEPAR for providing chemical data and field sampling support and to Laboratório de Ficologia UFPR for facilitating the use of the optical microscope.

\section{Author Contributions}

Angela Maria da Silva-Lehmkuhl: has substantial contribution in the concept and design of the study; data collection; data analysis and interpretation; manuscript preparation and to critical revision, adding intelectual content.

Priscila Izabel Tremarin: Has substantial contribution to data analysis and interpretation, and to critical revision, adding intelectual content.

Ilka Schincariol Vercellino: Has substantial contribution to data analysis and interpretation, and to critical revision, adding intelectual content.

Thelma A. Veiga Ludwig: has substantial contribution in the concept and design of the study; data collection; data analysis and interpretation; manuscript preparation and to critical revision, adding intelectual content.

\section{Conflicts of Interest}

The authors declare that they have no conflict of interest related to the publication of this manuscript.

\section{References}

ÁCS, E., KISS, K.T., SZABÓ, K. \& MAKK, J. 2000. Short-term colonization sequence of Periphyton on glass slides in a large river (River Danube, near Budapest). Algological Studies 100: 135-156.

ALLES, E., NÖRPEL-SCHEMPP, M. \& LANGE-BERTALOT, H. 1991. Zur Systematik und Ökologie charakteristischer Eunotia-Arten (Bacillariophyceae) in elektrolytarmen Bachoberläufen. Nova Hedwigia 53 (1-2): 171-213.

AZEVEDO, J.S., TALGATTI, D.M., TORGAN, L.C., PEREIRA, A.C. \& MELO, S. 2018. O genero Gomphonema (Bacillariophyta) na comunidade perifítica do rio e reservatório de Curuá-Una (Santarém, Pará, Brasil). Rodriguésia 69(2): 765-776. http://dx.doi.org/10.1590/2175-7860201869234

BAHLS, L.L. 2015. Kurtkrammeria, a new genus of freshwater diatoms (Bacillariophyta, Cymbellaceae) separated from Encyonopsis. Nova Hedwigia 101: 165-190. http://dx.doi.org/10.1127/nova_hedwigia/2015/0263

BARTOZEK, E.C.R., ZORZAL-ALMEIDA, S. \& BICUDO, D.C. 2018. Surface sediment and phytoplankton diatoms across a trophic gradient in tropical reservoirs: new records for Brazil and São Paulo State. Hoehnea 45(1): 69-92. http://dx.doi.org/10.1590/2236-8906-51/2017

BARTOZEK, E.C.R., BUENO, N.C., LUDWIG, T.A.V., TREMARIN, T.A.V., NARDELLI, M.S. \& ROCHA, A.C.R. 2013. Diatoms (Bacillariophyceae) of Iguaçu National Park, Foz do Iguaçu, Brazil. Acta Botanica Brasilica 27(1): 108-123. http://dx.doi.org/10.1590/S0102-33062013000100012
BERTOLLI, L.M., TREMARIN, P.I. \& LUDWIG, T.A.V. 2010. Diatomáceas perifíticas em Polygonum hydropiperoides Michaux, reservatório do Passaúna, Região Metropolitana de Curitiba, Paraná, Brasil. Acta Bot. Bras. 24(4):1065-1081. http://dx.doi.org/10.1590/S0102-33062010000400022

BEYENE, A., AWOKE, A. \& TRIEST, L. 2014. Validation of a quantitative method for estimating the indicator power of, diatoms for ecoregional river water quality assessment. Ecological Indicators 37: 58-66. http://dx.doi. org/10.1016/j.ecolind.2013.09.025

BICCA, A.B. \& TORGAN, L.C. 2009. Novos registros de Eunotia Ehrenberg (Eunotiaceae-Bacillariophyta) para o Estado do Rio Grande do Sul e Brasil. Acta Bot. Bras. 23(2): 427-435. http://dx.doi.org/10.1590/S010233062009000200014

BICUDO, C.E.M. \& MENEZES, M. 2017. Gêneros de algas de águas continentais do Brasil (Chave de identificação e descrições). 3 ed. Rima, São Carlos.

BICUDO, D.C., TREMARIN, P.I., ALMEIDA, P.D., ZORZAL-ALMEIDA, S., WENGRAT, S., FAUSTINO, S.B., COSTA, L.F., BARTOZEK, E.C.R., ROCHA, A.C.R., BICUDO, C.E.M. \& MORALES, E.A. 2016. Ecology and distribution of Aulacoseira species (Bacillariophyta) in tropical reservoirs from Brazil. Diat. Res. 31(3): 199-215. http://dx.doi.org/10.1080/026924 9X.2016.1227376

BICUDO, D.C., FONSECA, B.M., BINI, L.M., CROSSETI, L.O., BICUDO, C.E.M. \& ARAÚJO-JESUS, T. 2007. Undesirable side-effects of water hyacinth control in a shallow tropical reservoir. Freshwater Biology 52: 1120-1133. http://dx.doi.org/10.1111/j.1365-2427.2007.01738.x

BURKHOLDER, J.M. 1996. Interactions of benthic algae with their substrata. In Algal ecology: freshwater benthic ecosystems (R.J. Stevenson, M.L. Bothwell \& R.L. Lowe, eds). Academic Press, San Diego, p. 253-297.

CANANI, L.G.C., MENEZES, M. \& TORGAN, L.C. 2011. Diatomáceas epilíticas de águas oligotróficas e ácidas do Sudeste do Brasil. Acta Bot. Bras. 25(1): 130-140. http://dx.doi.org/10.1590/S0102-33062011000100016

CANTONATI, M. \& LANGE-BERTALOT, H. 2010. Diatom biodiversity of springs in the Berchtesgaden National Park (North-Eastern Alps, Germany), with the ecological and morphological characterization of two species new to science. Diat. Res. 25(2): 251-280. http://dx.doi.org/10.1080/026924 9X.2010.9705849

CANTONATI, M., KELLY, M.G. \& LANGE-BERTALOT, H. 2017. Freshwater benthic diatoms of Central Europe: over 800 common species used in ecological assessment. English edition with update taxonomy and added species. Schmitten-Oberreifenberg: Koeltz Botanical Books. p. 1-942.

CASA, V., MATALONI, G. \& VAN DE VIJVER, B. 2018. Six new Frustulia species (Bacillariophyta) in Tierra del Fuego peatbogs, Patagonia, Argentina. Fottea. 18(1): 55-71. http://dx.doi.org/10.5507/fot.2017.016

CASARTELLI, M.R., LAVAGNOLLI, G.J. \& FERRAGUT, C. 2016. Periphyton biomass accrual rate changes over the colonization process in a shallow mesotrophic reservoir. Acta Limnologica Brasiliensia 28: e9. http://dx.doi. org/10.1590/S2179-975X0116

CASCO, M.A., REYES, I., MARTÍN, G., FERNÁNDEZ, .R., SALA, S.E. \& TOJA, J. 2018. Phycological flora of the Guadalquivir river basin. Its value in determining the ecoregionalization of the basin. Limnetica 37(2): 239-248. http://dx.doi.org/10.23818/limn.37.20

CINIGLIA, C., CENNAMO, P., DE STEFANO, M., PINTO, G., CAPUTO, P. \& POLLIO, A. 2007. Pinnularia obscura Krasske (Bacillariophyceae, Bacillariophyta) from acidic environments: characterization and comparison with other acid-tolerant Pinnularia species. Fundamental and Applied Limnology Archiv für Hydrobiologie 170(1): 29-47. http://dx.doi. org/10.1127/1863-9135/2007/0170-0029

COSTA, L.F., WeTZEL, C.E., LANGE-Bertalot, H., ECTOR, L. \& BICUDO, D.C. 2017. Taxonomy and ecology of Eunotia species (Bacillariophyta) in southeastern Brazilian reservoirs. Biblioth. Diatomol. 64: 1-302.

CREMER, H., GORE, D., HULTZSCH, N., MELLES, M. \& WAGNER, B. 2004. The diatom flora and limnology of lakes in the Amery Oasis, East Antarctica. Polar Biol 27: 513-531. http://dx.doi.org/10.1007/s00300-004-0624-2 
CUNÃ-RODRÍGUEZ, C., PIOVANO, E., DEL PUERTO, L., INDA, H. \& GARCÍA-RODRÍGUEZ, F. 2018. On the relationship between holocene environmental variability and the diatomcomposition in the Peña Laggon, Se Uruguay. Ameghiniana 55(4): 423-436.

DARLING, J.P., GARLAND, D.D., STANISH, L.F., ESPOSITO, R.M.M., SOKOL, E.R. \& MCKNIGHT, D.M. 2017. Thermal autecology describes the occurrence patterns of four benthic diatoms in McMurdo Dry Valley streams. Polar Biol 40: 2381-2396. https://doi.org/10.1007/s00300-017-2151-y

DELA-CRUZ, J., PRITCHARD, T., GORDON, G. \& AJANI, P. 2006. The use of periphytic diatoms as a means of assessing impacts of point source inorganic nutrient pollution in south-eastern Australia. Freshwat. Biol. 51: 951-972. http://dx.doi.org/10.1111/j.1365-2427.2006.01537.x

DELGADO, C., NOVAIS, M.H., BLANCO, S. \& ALMEIDA, S.P. 2015. Examination and comparison of Fragilaria candidagilae sp. nov. with type material of Fragilaria recapitellata, F. capucina, F. perminuta, F. intermedia and F. neointermedia (Fragilariales, Bacillariophyceae). Phytotaxa. 231(1): 1-18. http://dx.doi.org/ 10.11646/phytotaxa.231.1.1

DIXIT, S.S. \& SMOL, J.P. 1995. Diatom evidence of past water quality changes in Adirondack Seepage Lakes (New York, U.S.A.). Diat. Res. 10(1): 113129. http://dx.doi.org/10.1080/0269249X.1995.9705331

FARIA, D.M., GUIMARÃES, A.T.B. \& LUDWIG, T.A.V. 2013. Responses of periphytic diatoms to mechanical removal to Pistia stratiotes L. in a hypereutrophic subtropical reservoir: dynammic and tolerance. Brazilian Journal of Biology 73(4): 681-689. http://dx.doi.org//10.1590/S151969842013000400002

FARIA, D.M., TREMARIN, P.I. \& LUDWIG, T.A.V. 2010. Diatomáceas perifíticas da represa Itaqui, São José dos Pinhais, Paraná: Fragilariales, Eunotiales, Achnanthales, e Gomphonema Ehrenberg. Biota Neotropica 10(3): http://www.biotaneotropica.org.br/v10n3/pt/abstract?inventory+ bn 04110032010

FAUSTINO, S.B., FONTANA, L., BARTOZEK, E.C.R., BICUDO, C.E.M. \& BICUDO, D.C. 2016. Composition and distribution of diatom assemblages from core and surface sediments of a water supply reservoir in Southeastern Brazil. Biota Neotropica: 16(2): e20150129. http://dx.doi.org/10.1590/16760611-BN-2015-0129

FELL, S.C., CARRIVICK, J.L., KELLY, M.G., FÜREDER, L. \& BROWN, L.E. 2018. Declining glacier cover threatens the biodiversity of alpine river diatom assemblages. Global Change Biology 24: 5828-5840. http://dx.doi. org/ 10.1111/gcb.14454

FERRARI, F., PROCOPIAK, L.K., ALENCAR, Y.B. \& LUDWIG, T.A.V. 2007. Eunotiaceae (Bacillariophyceae) em igarapés da Amazônia Central, Manaus e Presidente Figueiredo, Brasil. Acta Amaz. 37(1): 1-16. http://dx.doi.org/10.1590/S0044-59672007000100001

FRANÇA, A.A., DUNCK, B., RODRIGUES, L., FONSECA, B.M. \& FELISBERTO, S.A. 2017. Periphytic diatoms (Bacillariophyta) in streams from three Conservation Units of centra Brazil: Pinnularia Ehrenberg. Hoehnea 44(4): 524-538. http://dx.doi.org/10.1590/2236-8906-107/2016

FRÁNKOVÁ, M., BOJKOVÁ, J., POULÍČKOVÁ, A. \& HAJÉK, M. 2009. The structure and species richness of the diatom assemblages of the Western Carpathian pring fens long the gradient of mineral richness. Fottea $9(2)$ : 355-368. http://dx.doi.org/10.5507/fot.2009.035

GOLDSBOROUGH, L.G. \& ROBINSON, G.C.C. 1996. Pattern in wetlands. In: Algal ecology: freshwater benthic ecosystems (R.J. Stevenson, M.L. Bothwell \& R.L. Lowe, eds). Academic Press, New York, p. 77-117.

GÓMÉZ, N. \& LICURSI, M. 2001. The Pampean Diatom Index (IDP) for assessment of rivers and streams in Argentina. Aquatic Ecol. 5: 173-181. http://dx.doi.org/10.1023/A:1011415209445

GUIMARÃES, L.J.R. 2008. Levantamento das áreas potenciais ao assoreamento da barragem Piraquara I. Dissertação de Mestrado, Universidade Federal do Paraná Curitiba.

GUIRY, M.D. 2012. How many species of algae are there? Journal of Phycology 48: 1057-1063. http://dx.doi.org/10.1111/j.1529-8817.2012.01222.x

HÅKANSSON, S. 1993. Numerical methods for the inference of $\mathrm{pH}$ variations in mesotrophic and eutrophic lakes in Southern Sweden - a progress report. Diat. Res. 8(2): 349-370. http://dx.doi.org/10.1080/0269249X.1992.9705208
HOFMANN, G. 1994. Aufwuchs-Diatomeen in Seen und ihre Eignung als Indikatoren der Trophie. Biblioth. Diatomol. J. Cramer, Berlin - Stuttgart, 30.

HOFMANN, G., WERUM, M. \& LANGE-BERTALOT, H. 2013. Diatomeen im Süßwasser - Benthos von Mitteleuropa. Bestimmungsflora Kieselalgen für die ökologische Praxis. Über 700 der häufigsten Arten und ihre Ökologie. Koeltz Scientific Books, Königstein.

HUSTEDT, F. 1927-1930. Die Kieselalgen. In Kryptogamen-Flora (L. Rabenhorst, ed). Akademische Verlagsgesellschaft, Leipzig, 7(1): 1-920.

HUSTEDT, F. 1931-1959. Die Kieselalgen. In Kryptogamen-Flora (L. Rabenhorst, ed). Akademische Verlagsgesellschaft, Leipzig, 7(2):1-845.

HUSTEDT, F. 1961-1966. Die Kieselalgen. In Kryptogamen-Flora (L. Rabenhorst, ed). Akademische Verlagsgesellschaft, Leipzig, 7(3): 1-816.

IVANOV, P. \& KIRILOVA, E. 2004. Benthic diatoms assemblages from different substrates of the Iskar river, Bulgaria. In Proceeding of the Eighteenth International Diatom Symposium, Miedzyzdroje, Poland (A. Witkowski, ed). p. 107-124.

JAHN, R., KUSBER, W-H. \& LANGE-BERTALOT, H. 2014. Typification and taxonomy of Hantzschia amphioxys (Ehrenberg) Grunow (Bacillariophyta): type of the genus name Hantzschia Grunow. Nova Hedwigia 143: 103-110. http://dx.doi.org/ 10.1127/1438-9134/2014/005

JOHANSEN, J., KOCIOLEK, P. \& LOWE, R. 2008. Spicaticribra kingstonii, gen. nov. et. sp. nov. (Thalassiosirales, Bacillariophyta) from Great Smoky Mountains National Park, USA. Diat. Res. 23(2): 367-375. http://dx.doi.or g/10.1080/0269249X.2008.9705763

JÚLIO JÚNIOR, H. F., THOMAZ, S. M., AOSTINHO, A. A., LATINI, J. D. 2005. Distribuição e caracterização dos reservatórios. In: RODRIGUES, L., THOMAZ, S. M., AGOSTINHO, A. A. \& GOMES, L. C. (Eds). Biocenoses em reservatórios: padrões espaciais e temporais. São Carlos: Rima. cap. 1. p. 1-16.

KARTHICK, B. \& KOCIOLEK, P. 2012. Reconsideration of the Gomphonema (Bacillariophyceae) species from Kholhapur, Northern Western Ghats, India: Taxonomy, typification and biogeography of the species reported by H. P. Gandhi. Phycological Research 60: 179-198. http://dx.doi.org/10.1111/ j.1440-1835.2012.00649.x

KOCIOLEK, J.P. \& STOERMER, E.F. 2009. Oligotrophy: the forgotten end of an ecological spectrum. Acta Bot. Croat. 68: 465-472.

KOPALOVÁ, K., KOCIOLEK, J.P., LOWE, R.L., ZIDAROVA, R. \& VAN DE VIJVER, B. 2015. Five new species of the genus Humidophila (Bacillariophyta) from the Maritime Antarctic Region. Diatom Research 30(2): 117-131. http://dx.doi.org/10.1080/0269249X.2014.998714

KRAMMER, K. 1997a. Die cymbelloidean Diatomeen: eine Monographie der weltweit bekannten taxa. I Allgemeines und Encyonema part. Biblioth. Diatomol. 36: 1-382.

KRAMMER, K. 1997b. Die cymbelloidean Diatomeen: eine Monographie der weltweit bekannten taxa. II Encyonema part., Encyonopsis and Cymbellopsis. Biblioth. Diatomol. 37: 1-469. Verlag KG, Ruggell, v. 3, 584 p.

KRAMMER, K. 1992. Pinnularia, eine Monographie der europäischen Taxa. Bibliotheca Diatomologica, Stuttgart, 26.

KRAMMER, K. 2000. The genus Pinnularia. In Diatoms of Europe $1(\mathrm{H}$. Lange-Bertalot) p. 1-703.

KRAMMER, K. \& LANGE-BERTALOT, H. 1986. Bacillariophyceae: Naviculaceae. In Süsswasserflora von Mitteleuropa (H. Ettl, J. Gerloff, H. Heynig, D. Mollenhauer, eds). Gustav Fischer, Jena. v. 2, pars 1, 876 p.

KRAMMER, K. \& LANGE-BERTALOT, H. 1988. Bacillariophyceae: Bacillariaceae, Epithemiaceae, Surirellaceae. In Süsswasserflora von Mitteleuropa (H. Ettl, J. Gerloff, H. Heynig, D. Mollenhauer, eds). Gustav Fischer, Stuttgart. v. 2,pars 2, 596 p.

KRAMMER, K. \& LANGE-BERTALOT, H. 1991a. Bacillariophyceae: Centrales, Fragilariaceae, Eunotiaceae. In Süsswasserflora von Mitteleuropa (H. Ettl, J. Gerloff, H. Heynig, D. Mollenhauer, eds). Gustav Fischer, Stuttgart. v. 2, pars 3, 576 p.

KRAMMER, K. \& LANGE-BERTALOT, H. 1991b. Bacillariophyceae: Achnanthaceae. Kritische Ergänzungen zu Navicula (Lineolatae) und Gomphonema. In Süsswasserflora von Mitteleuropa (H. Ettl, J. Gerloff, H. Heynig, D. Mollenhauer, eds). Gustav Fischer, Stuttgart. v. 2, pars 4, 437 p. 
KRASSKE, G. 1948. Diatomeen tropischer Moosrasen. Svensk Botanisk Tidskrift 42(4): 404-443.

KRSTIĆ, S.S., ZECH, W., OBREHT, I., SVIRČEV, Z. \& MARCOVIĆ, S.B. 2012. Late quaternary environmental changes in Helambu Himal, Central Nepal, recorded in the diatom flora assemblage composition and geochemistry of Lake Panch Pokhari. J. Paleolimnol. 47: 113-124. https://doi.org/10.1007/s10933-011-9563-4

KRSTIĆ, S.S., PAVLOV, A., LEVKOV, Z. \& JÜTTNER, I. 2013. New Eunotia taxa in core samples from Lake Panch Pokhari in the Nepalese Himalaya. Diat. Res. 28(2): 203-217. http://dx.doi.org/10.1080/026924 9X.2013.782343

KULIKOVSKIY, M.S., LANGE-BERTALOT, H., WITKOWSKI, A., DOROFEYUK, N.I. \& GENKAL, S.I. 2010. Diatom assemblages from Sphagnum bogs of the world. I. Nur bog in northern Mongolia. Biblio. Diatomol. 55: 1-326.

LANGE-BERTALOT, H. 1993. 85 Neue Taxa und über 100 weitere neu definierte Taxa ergänzend zur Süsswasserflora von Mitteleuropa. Bibliotheca Diatomologica 27: 1-164.

LANGE-BERTALOT, H. 1999. Neue Kombinationen von Taxa aus Achnanthes Bory (sensu lato). In Iconogr. Diatomol., Annotated Diatom Monographs (H. Lange-Bertalot, ed.). Gantner Verlag KG, Ruggell, 6:276-289.

LANGE-BERTALOT, H. 2001. Navicula sensu stricto. 10 Genera separated from Navicula sensu lato. Frustulia. Diatoms of Europe: diatoms of the European inland waters and comparable habitats. Ruggell: A.R.G. Gantner Verlag. K.G. 2:1-526.

LANGE-BERTALOT, H. \& MOSER, G. 1994. Brachysira Monographie der Gattung. Wichtige Indikator Species für das Gewässermonitoring und Naviculadicta nov. gen. Biblio. Diatomol. 29: 1-212.

LANGE-BERTALOT, H. \& METZELTIN, D. 1996. Indicators of oligotrophy-800 taxa representative of three ecologically distinct lake types, Carbonate buffered-Oligodystrophic-Weakly buffered soft water. In Iconogr. Diatomol. (H. Lange-Bertalot, ed.). Gantner Verlag KG, Ruggell, 2:1-390.

LANGE-BERTALOT, H. \& METZELTIN, D. 2009. A dystrophic mountain lake in Panama - Hot spot of new and rare neotropical diatoms. Nova Hedwigia. 135: 137-166

LANGE-BERTALOT, H., METZELTIN, D. \& WITKOWSKI, A. 1996 Hippodontagen. nov.-Umschreibung und begründung einer Gattung der Naviculaceae. In Iconogr.Diatomol (H. Lange-Bertalot, ed.). Gantner Verlag KG, Ruggell, 4: 247-275.

LANGE-BERTALOT, H.; BAK, M. \& WITKOWSKI, A. 2011. Eunotia and some related genera. In: Diatoms of Europe (Lange-Bertalot, H., ed.). Königstein, Koeltz Scientific Books, 6.

LAMPARELLI, M.C. 2004. Grau de trofia em corpos d'água do estado de São Paulo: avaliação dos métodos de monitoramento. Tese de doutorado, Universidade de São Paulo, São Paulo.

LESKINEN, E. \& HÄLLFORS, G. 1990. Community structure of epiphytic diatoms in relation to eutrophication on the Hanko Peninsula, south coast of Finland. In: Proceeding of the Thent International Diatom Symposium (H. Simola, ed.). Koeltz Scientific Books, Koenigstein, p. 323-333.

LEVKOV, Z., KRSTIC, S., METZELTIN, D. \& NAKOV, T. 2007. Diatoms of Lakes Prespa and Ohrid. In Iconogr. Diatomol. (H. Lange-Bertalot, ed.). Gantner Verlag KG, Ruggell, 16: 1-613.

LOBO, E.A., CALLEGARO, V.L.M. \& BENDER, E.P. 2002. Utilização de algas diatomáceas epilíticas como indicadores da qualidade da água em rios e arroios da região hidrográfica do Guaíba, RS, Brasil. EDUNISC, Santa Cruz do Sul, 127p.

LOWE, R.L. 1996. Periphyton patterns in lakes. In: Algal ecology: freshwater benthic ecosystems (R.J. Stevenson, M.L. Bothwell \& R.L. Lowe, eds). Academic Press, New York, p. 57-76.

LOWE, R.L. \& PAN, Y. 1996. Benthic algal communities as biological monitors In: Algal ecology: freshwater benthic ecosystems (R.J. Stevenson, M.L. Bothwell \& R.L. Lowe, eds). Academic Press, New York, p. 705-739.
LUDWIG, T.A.V., TREMARIN, P.I., BECKER, V. \& TORGAN, L.C. 2008. Thalassiosira rudis sp. nov. (Coscinodiscophyceae): a new freshwater species. Diat. Res. 23(2): 389-400. http://dx.doi.org/10.1080/026924 9X.2008.9705765

MA, Y., LI, G., LI, J., ZHOU, H. \& JIANG, B. 2014. Seasonal succession of phytoplankton community and its relationship with environmental factors of North Temperate Zone water of the Zhalong wetland, in China Ecotoxicology 23: 618-625. http://dx.doir.org/10.1007/s10646-014-1231-9

MANN, D.G. \& VANORMELIGEN, P. 2013. An inordinate fondness? The number, distributions, and origins of diatom species. The Journal of Eukaryotic Microbiology 60: 414-420. http://dx.doi.org/10.1111/jeu.12047

MARRA, R.C., TREMARIN, P.I., ALGARTE, V.M. \& LUDWIG, T.A. 2016. Epiphytic diatoms (Diatomeae) from Piraquara II urban reservoir, Paraná state. Biotaneotropica 16(4): e20160200. http://dx.doi.org/10.1590/16760611-BN-2016-0200

MARQUARDT, G.C. \& BICUDO, C.E.M. 2014. Criptógamos do Parque Estadual das Fontes do Ipiranga, São Paulo, SP. Algas 36: Bacillariophyceae (Cymbellales). Hoehnea 41(2): 209-246. http://dx.doi.org/10.1590/S223689062014000200005

MARQUARDT, G.C., ROCHA, A.C.R., WETZEL, C.E., ECTOR, L. \& BICUDO, C.E.M. 2016. Encyonema aquasedis sp. nov. and Kurtkrammeria salesopolensis sp. nov.: two new freshwater diatom species (Cymbellales, Bacillariophyceae) from an oligotrophic reservoir in southeastern Brazil. Phytotaxa 247(1): 62-74.

MARQUARDT, G.C., WENGRAT, S., BICUDO, D.C., WETZEL, C.E., ECTOR, L. \& BICUDO, C.E.M. 2017. Morphology and distribution of Encyonema angustecapitatum Krammer species complex (Bacillariophyceae) with description of four new species from São Paulo, southeast Brazil. Fottea 17(2): 164-177. http://dx.doi.org/10.5507/fot.2017.008

MARQUARDT, G.C., BICUDO, C.E.M., LUDWIG, T.A.V., ECTOR, L. \& WETZEL, C.E. 2018. Diatom assemblages (Bacillariophyta)in six tropical reservoirs from southeast Brazil: species composition and spatial and temporal variation patterns. Acta Limnologica Brasiliensia 30: e201. https://doi.org/10.1590/S2179-975X6417

MEDEIROS, G., AMARAL, M.W.W., FERREIRA, P.C., LUDWIG, T.A.V. \& BUENO, N.C. 2018. Gomphonema Ehrenberg (Bacillariophyceae, Gomphonemataceae) of the São Francisco Falso River, Paraná, Brazil. Biota Neotropica 18(3): e20170495. http://dx.doi.org/10.1590/1676-0611BN-2017-0495

MELO, E.F. 2008. Flora da Serra do Cipó, Minas Gerais: Polygonaceae. Bol. Bot. Univ. São Paulo. 26(2): 165-174. http://dx.doi.org/10.11606/issn.23169052.v26i2p165-174

METZELTIN, D. \& LANGE-BERTALOT, H. 1998. Tropical diatoms of South America I. About 700 predominantly rarely known or new taxa representative of the neotropical flora. In Iconogr. Diatomol. $(\mathrm{H}$ Lange-Bertalot, ed.) 5: 1-695.

METZELTIN, D. \& LANGE-BERTALOT, H. 2002. Diatoms from the "Island Continent" Madagascar. In Iconogr. Diatomol (H. Lange-Bertalot, ed.) Gantner Verlag KG, Ruggell, 11: 1-286.

METZELTIN, D. \& LANGE-BERTALOT, H. 2005. Diatoms of Uruguay. Compared with other taxa from South America and elsewhere. In Iconogr. Diatomol (H. Lange-Bertalot, ed.). Gantner Verlag KG, Ruggell, 15:1-736.

METZELTIN, D. \& LANGE-BERTALOT, H. 2007. Tropical Diatoms of South America II. Special remarks on biogeographic disjunction. In Iconogr. Diatomol (H. Lange-Bertalot, ed.). Gantner Verlag KG, Ruggell, 18:1-877.

METZELTIN, D., LANGE-BERTALOT, H. \& SONINKHISHING, N. 2009. Diatoms in Mongolia. In Iconogr.Diatomol (H. Lange-Bertalot, ed.). Gantner Verlag KG, Ruggell, 20: 3-686.

MONTOYA-MORENO, Y., SALA, S., VOUILLOUD, A. \& AGUIRRE, N. 2011. Capartogramma crucicula (Grunow ex Cleve) Ross, primer registro del género para Colombia. Universitas Scientiarum 16(1): 70-76.

MOREIRA-FILHO, H. \& VALENTE MOREIRA, I.M. 1981. Avaliação taxonômica e ecológica das diatomáceas (Bacillariophyceae) epífitas em algas pluricelulares obtidas nos litorais dos Estados do Paraná, Santa Catarina e São Paulo. Bol. Mus. Bot. Mun. 47: 1-17. 
MOSER, G., LANGE-BERTALOT, H. \& METZELTIN, D. 1998. Insel der Endemiten Geobotanisches Phänomen Neukaledonien (Island of endemics New Caledonia - a geobotanical phenomenon). Bibliotheca Diatomologica 38:464 pp.

MURDOCK, J.N. \& DODDS, W.K. 2007. Linking benthic algal biomass to stream substratum topography. Journal of Phycological 43: 449-460. http://dx.doi.org/10.1111/j.1529-8817.2007.00357.x

NOGA, T., PESZEK, Ł., STANEK-TARKOWSKA, J. \& PAJACZEK, A. 2014. The Pinnularia genus in south-eastern Poland with consideration of rare and new taxa to Poland. Oceanological and Hydrobiological Studies 43(1): 77-99. http://dx.doi.org/10.2478/s13545-014-0120-4

OSÓRIO, N.C., TREMARIN, P.I., LUDWIG, T.V. \& RODRIGUES, L. 2017. Gomphonema Ehrenberg (Bacillariohyceae) in a lotic environment of the Upper Paraná River floodplain, Brazil. Acta Scientiarum. 39(2): 135-147. http://dx.doi.org/10.4025/actascibiolsci.v39i2.32134

PATRICK, R. \& REIMER, C.W. 1966. The diatoms of United States: exclusive of Alaska and Hawaii. Acad. Nat. Sci. Philadelphia, Monographs, 13(1): 1-688.

PESTRYAKOVA, L.A., HERZSCHUH, U., GORODNICHEV, R. \& WETTERICH, S. 2018. The sensitivity of diatom taxa from Yakutian lakes (north-eastern Siberia) to electoral conductivity nd other environmental variables. Polar Research 37:1485625. https://doi.org/10.1080/17518369 .2018 .1485625

POTAPOVA, M. \& CHARLES, D.F. 2007. Diatom metrics for monitoring eutrophication in rivers of the United States. Ecol. Indic. 7: 48-70. http://dx.doi.org/10.1016/j.ecolind.2005.10.001

POULÍČKOVÁ, A., ŠPAČKOVÁ, J., KELLY, M.G., DUCHOSLAV, M. \& MANN, D.G. 2008. Ecological variation within Sellaphora species complexes (Bacillariophyceae): specialists or generalists? Hydrobiologia 614: 373-386. http://dx.doi.org/10.1007/s10750-008-9521-y

REICHARDT, E. 1995. Die Diatomeen (Bacillariophyceae) in Ehrenberg's material von Cayenne, Guyana Gallica (1843). In Iconogr. Diatomol. (H. Lange-Bertalot, ed.) 1: 1-107.

REICHARDT, E. 2015a. Gomphonema gracile Ehrenberg sensu stricto et sensu auct. (Bacillariophyceae): A taxonomic revision. Nova Hedwigia. 101(3-4): 367-393. http://dx.doi.org/10.1127/nova hedwigia/2015/0275

REICHARDT, E. 2015b. Taxonomy and distribution of Gomphonema subtile Ehrenberg (Bacillariophyceae) and six related taxa. Fottea. 15(1): 27-38. http://dx.doi.org/10.5507/fot.2015.003

RIATO, L., LEIRA, M., DELLA BELLA, V. \& OBERHOLSTER, P.J. 2017. Diatom-based models for inferring water chemistry and hydrology in temporary depressional wetlands. Hydrobiologia 797: 127-143. http://dx.doi. org/ 10.1007/s10750-017-3165-8

RIMET, F., BOUCHEZ, A. \& MONTUELLE, B. 2015. Benthic diatoms and phytoplankton to assess nutrient in large lakes: complementarity of their use in Lake Geneva (France-Switzerland). Ecol. Indic. 53: 231-239. http://dx.doi.org/10.1016/j.ecolind.2015.02.008

RIVERA, P. \& CRUCES, F. 2013. Spicaticribra kingstonii Johansen, Kociolek \& Lowe (Thalassiosirales, Bacillariophyta): primera cita del género y de la especie para las aguas continentales de Chile. Gayana Bot. 70(2): 235-240. http://dx.doi.org/10.4067/S0717-66432013000200004

ROUND, F.E., CRAWFORD, R.M. \& MANN, D.G. 1990. The diatoms. Biology and morphology of the genera. New York, Cambridge University Press, p. 129.

RUCK, E.C., NAKOV, T., ALVERSON, A.J. \& THERIOT, E.C. 2016. Nomenclatural transfers associated with the phylogenetic reclassification of the Surirellales and Rhopalodiales. Notulae Algarum 10:1-4.

SALA, S.E., PLATA-DÍAZ, Y., PEDRAZA, E. \& PIMIENTA, A. 2015. Taxonomía y distribucíon de diatomeas epilíticas registradas por primera vez en Colombia. Caldasia 37(1): 125-141. http://dx.doi.org/10.15446/ caldasia.v37n1.50814

SANTOS, E.M., TREMARIN, P.I. \& LUDWIG, T.A.V. 2011. Diatomáceas perifiticas em Potamogeton polygonus Cham. \& Schltdl.: citações pioneiras para o estado do Paraná. Biota Neotropica 11(3): http://www.biotaneotropica. org.br/v11n3/pt/abstract?inventory+bn01611032011
SANTOS, T.R. \& FERRAGUT, C. 2018. Changes in the taxonomic structure of periphytic algae on free-loating crophyte (Utricularia foliosa $\mathrm{L}$.) in relation to macrophyte richness over season. Acta Botanica Brasilica 32(4): 595-601. http://dx.doi.org/10.1590/0102-33062018abb0031

SAYER, C.D, ROBERTS, N., SADLER, J., DAVID, C. \& WADE, P.M. 1999. Biodiversity changes in a shallow lake ecosystem: a multi-proxy palaeolimnological analysis. Journal of Biogeography 26(1): 97-114. http://dx.doi.org/10.1111/j.1365-2699.1999.00298.x

SIENKIEWICZ, E. 2005. Comparison of subfossil diatoms (Bacillariophyta) from two oligotrophic lakes: Maly Staw (Karkonosze MTS., Poland) and Somaslampi (Lapland, Finland). Polish Geological Institute Special Papers. 16: 109-115.

SILVA, A.M., TREMARIN, P.I., LUDWIG, T.A.V. \& VERCELLINO, I.S. 2010 Diatomáceas perifíticas em um sistema eutrófico brasileiro (Reservatório do Iraí, estado do Paraná). Acta Botanica Brasilica. 24(4): 997-1016. http://dx.doi.org/10.1590/S0102-33062010000400015

SIMONSEN, R. 1974. The diatom plankton of the Indian Ocean Expedition of R/V “Meteor", 1964-65 Meteor. Forschungsergebnisse Reihe D-Biologie. 19: 1-66.

SIVER, P.A. \& KLING, H. 1997. Morphological observations of Aulacoseira using scanning electron microscopy. Can. J. Bot. 75: 1807-1835. http://dx.doi.org/10.1139/b97-894

SOUZA, M.L. \& FERRAGUT, C. 2012. Influence of substratum surface roughness on periphytic algal community structure in a shallow tropical reservoir. Acta Limnol. Bras. 24(4): 397-407. http://dx.doi.org/10.1590/ S2179-975X2013005000004

SPAULDING, S. \& EDLUND, M. 2009. Pinnularia. In Diatoms of the United States. Retrieved November 20, 2017, from http://westerndiatoms.colorado. edu/taxa/genus/Pinnularia

STENGER-KOVÁCS, C., BUCZKÓ, K., HAJNAL, E. \& PADISÁK, J. 2007. Epiphytic, littoral diatoms as bioindicators of shallow lake trophic status: Trophic diatom index for lakes (TDIL) developed in Hungary. Hydrobiol. 589: 141-154. http://dx.doi.org/10.1007/s10750-007-0729-z

STRAUBE, A., TREMARIN, P.I. \& LUDWIG, T.A.V. 2017. Species of Luticola D. G. Mann (Bacillariophyceae) in the Atlantic Forest rivers from southern Brazil. Diatom Research 32(4): 417-437. http://dx.doi.org/10.1080/02692 49X.2017.1389771

SUDERHSA, 2007. http://www.aguasparana.pr.gov.br/modules/conteudo/ conteudo.php?conteudo $=80$ (Acessed 06 September 2017).

SZULC, K., BESENYEI, L., SZULC, B. \& RAKOWSKA, B. 2014. Diatomological aspects of the Fenn's and Whixall mosses complex (Shropshire, UK). Oceanological and Hydrobiological Studies 43(3): $274-$ 282. http://dx.doi.org/10.2478/s13545-014-0142-y

TORRISI, M., SCURI, S., DELL'UOMO, A. \& COCCHIONI, M. 2010. Comparative monitoring by means of diatoms, macroinvertebrates and chemical parameters of an Apennine watercourse of central Italy: The river Tenna. Ecol. Indic., 10: 910-913. http://dx.doi.org/10.1016/j. ecolind.2010.01.010

TREMARIN, P.I., MOREIRA-FILHO, H. \& LUDWIG, T.A.V. 2010. Pinnulariaceae (Bacillaiophyceae) do rio Guaraguaçu, bacia litorânea paranaense, Brasil. Acta Botanica Brasilica 24(2): 335-353.

TREMARIN, P.I., FREIRE, E.G., BERTOLLI, L.M. \& LUDWIG, T.A.V. 2009. Catálogo das diatomáceas (Ochrophyta-Diatomeae) continentais do estado do Paraná. Iheringia - Sér. Bot. 64(2): 79-107.

TUJI, A. \& WILLIAMS, D.M. 2007. Type examination of Japanese diatoms described by Friedrich Meister (1913) from lakes Suwa. Bull. Natn. Sci. Mus. 33(2): 69-79.

TUNDISI, J.G. 2003. Água no século XXI: enfrentando a escassez. RiMa: São Carlos - SP, p. 1-248.

VAN DAM, H., MERTENS, A. \& SINKELDAM, J. 1994. A coded checklist and ecological indicator values of freshwater diatoms from the Netherlands. Neth. J. Aquatic Ecol. 28(1): 117-133. http://dx.doi.org/10.1007/BF02334251

VAN DE VIJVER, B., GREMMEN, N.J. \& BEYENS, L. 2005. The genus Stauroneis (Bacillariophyceae) in the Antartic region. J. Biogeogr. 32: 17911798. http://dx.doi.org/10.1111/j.1365-2699.2005.01325.x 
Periphytic diatoms from an oligotrophic reservoir

VAN DE VIJVER, B. \& BEYES, L. 1997. The epiphytic diatom flora of mosses from Strømness Bay area, South Georgia. Polar Biol 17: 492-501. http://dx.doi.org/10.1007/s003000050148

VANHOUTTE, K., VERLEYEN, E., VYVERMAN, W., CHEPURNOV, V, \& SABBE, K. 2004. The freshwater diatom genus Kobaysiella (Bacillariophyta) in Tasmania, Australia. Australian Systematic Botany 17:483-496. http://dx.doi.org/10.1071/SB03035

VESELÁ, J. 2009. Spatial heterogeneity and ecology of algal communities in an ephemeral sandstone stream in the Bohemian Switzerland National Park, Czech Republic. Nova Hedwigia 88(4-3): 531-547. http://dx.doi.org/ 10.1127/0029-5035/2009/0088-0531

WANG, R., XU, M., YANG, H., YANG, X., ZHANG, K., ZHANG, E. \& SHEN, J. 2019. Ordered diatom species loss along a total phosphorous gradient in eutrophic lakes of the lower Yangtze River basin, China Science of the Total Environment 650: 1688-1695. https://doi.org/10.1016/j. scitotenv.2018.09.328

WENGRAT, S., MARQUARDT, G.C., BICUDO, D.C., BICUDO, C.E.M., WETZEL, C.E. \& ECTOR, L. 2015. Type analisys of Cymbella schubartii and two new Encyonopsis species (Bacillariophyceae) from southeastern Brazil. Phytotaxa 221(3): 247-264. http://dx.doi.org/10.11646/ phytotaxa.221.3.3
WENGRAT, S., MORALES, E.A., WETZEL, C.E., ALMEIDA, P.D., ECTOR, L. \& BICUDO, D.C. 2016. Taxonomy and ecology of Fragilaria billingsii sp. nov. and analysis of type material of Synedra rumpens var. fusa (Fragilariaceae, Bacillariophyta) from Brazil. Phytotaxa. 270(3): 191-202. http://dx.doi.org/10.11646/phytotaxa.270.3.3

WENGRAT, S., PADIAL, A.A., JEPPESEN, E., DAVIDSON, T.A., FONTANA, L., COSTA-BÖDDEKER \& BICUDO, D.C. 2017. Paleolimnological records reveal a biotic homogenization driven by eutrophication in tropical reservoirs. J. Paleolimnol https://doi.org/10.1007/s10933-017-9997-4

WETZEL, C.E., VAN DE VIJVER, B., HOFFMANN, L. \& ECTOR, L. 2013. Planothidium incuriatumsp. nov. a widely distributed diatom species (Bacillariophyta) and type analysis of Planothidium biporomum. Phytotaxa. 138(1): 43-57. http://dx.doi.org/10.11646/phytotaxa.138.1.6

WOLFE, A.P. \& KLING, H.J. 2015. A consideration of some North American soft-water Brachysira taxa and description of B. arctoborealis sp. nov. Studies on Diatoms. 243-264.

YANG, J.R. \& DICKMAN, M. 1993. Diatoms as indicators of lake trophic status in central Ontario, Canada. Diat. Res. 8(1): 179-193. http://dx.doi.org/10.1 080/0269249X.1993.9705249

ZORZAL-ALMEIDA, S., BICUDO, D.C., LAMPARELLI, M.C., FERRAGUT, C. \& BICUDO, C.E.M. 2017. Avaliação do índice de estado trófico e sua aplicação na represa Guarapiranga em longa série temporal. In: 100 Anos da represa Guarapiranga: lições e desafios (Bicudo, C.E.M. \& Bicudo, D.C., eds). Editora CRV, Curitiba-PR, Brasil. p. 401-428.

Received: $25 / 04 / 2018$

Revised: 16/12/2018

Accepted: $21 / 02 / 2019$

Published online: 28/03/2019 